БЪЛГАРСКА АКАДЕМИЯ НА НАУКИТЕ

ИЗВЕСТИЯ НА ИНСТИТУТА ЗА БЪЛГАРСКИ ЕЗИК „ПРОФ. ЛЮБОМИР АНДРЕЙЧИН“

Кн иг а XXXIII

ПОЯСНЕНИТЕ ДУМИ В СРЕДНОРОДОПСКИТЕ ВЪЗРОЖДЕНСКИ ПИСМЕНИ ПАМЕТНИЦИ С ГРЫЦКО ПИСМО

(Особености и тенденции в речниковото вариране)

Георги Митринов

Институт за български език, БАН

\title{
EXPLAINED WORDS IN THE MIDDLE RHODOPE REVIVAL WRITTEN MONUMENTS WITH GREEK LETTERING (Features and trends in vocabulary variation)
}

\author{
Georgi Mitrinov \\ Institute for Bulgarian Language, Bulgarian Academy of Sciences
}

Резюме. Проучването на лексиката във възрожденските писмени паметници е важно за историята на българския език. В статията се разглеждат лексикални особености на среднородопски възрожденски писмени паметници. Съпоставя се лексика от чужд произход (гръцки и турски), включена в текстовете. Проучва се синонимията, появила се от употребата на думи от български произход, с които се поясняват включените в текстовете чужди думи.

Ключови думи: Родопско възраждане, история на българския език, родопска възрожденска писмена традиция, лексикални особености

Abstract. The study of vocabulary in Revival written monuments is important for the history of the Bulgarian language. The article deals with the lexical features of middle Rhodopes Revival written monuments. The vocabulary of foreign origin (Greek and Turkish) included in the texts is compared. It studies the synonymy arising from the use of Bulgarian origin words that explain the foreign words included in the text.

Keywords: Rhodopean revival, history of Bulgarian ranguage, Rhodope revival written tradition, lexical features 


\section{1. Езикова ситуация по българските земи през Възраждането}

Езиковата ситуация по българските земи през Възраждането има свои общи, както и специфични за отделни райони на българското езиково землище особености ${ }^{1}$. От една страна, това е наличието на официален език в Османската империя - османски турски, който е чужд за българите. Но като език на администрацията, на официалната власт, е трябвало да бъде усвояван от българоезичното население в империята, което е свързано с неговото препитание и оцеляване. Това важи повече за мъжкото население, докато за жените, които се занимавали основно с отглеждането на децата, с къщната работа и със селскостопанска дейност в селата, не било важна необходимост да владеят турски език. Освен това в районите, населени с българско християнско население, силни позиции имала Грьцката патриаршия, както и свързаните с нея проводници на гърцизма - търговци и занаятчии гърци и българи гъркомани, покровителствани от религиозната институция. Това особено важи за южните краища на българското езиково землище (Източна Тракия, Беломорието, Родопите), където силното гръцко езиково влияние продължава на места дори чак до Балканската война (1912-1913 г.).

Такава е картината и в Среднородопието (днешно Смолянско). Специфика тук е наличието на преобладаващо българско мюсюлманско население, което доминира над малоборойното местно еднородно българско християнско население, оцеляло след масовите помюсюлманчвания в най-обширната българска планина. Местните българи християни се занимавали с животновъдство, като основен поминък било трансхуманното животновъдство, свързано с отглеждането на овце. Многобройните стада през пролетта, лятото и есента пребивавали по високопланинските пасища в Среднородопието, а зимували в Беломорието (в Гюмюрджинско и в Ксантийско). Малка част от тях, в северните части на Среднородопието, зимували в Горнотракийската низина (Пловдивско и Първомайско). Развитото овцевъдство било предпоставка за появата на занаяти, свързани с него, като абаджийството, а по-късно и терзийството, които станали основни за среднородопското християнско население. Важно място в бита на среднородопските християни заемат трудови заетости като бакърджийството, дюлгерството (зидарството), рибарството и др. (Гиневски/Ginevski 2008, 31-32, 38, 40, 42). Развитието на животновъдството и занаятчийството способстват за появата на заможни представители от средите на българите християни в Среднородопието. Възниква местна интелигенция, която постепенно дораства до идеите за просвета и религиозни свободи на местното българско християнско население. Но гръцкото влияние в религиозното и просветното дело е много силно. За него свидетелства спо-

${ }^{1}$ Публикацията е написана във връзка с работата по съвместния проект на Секцията за история на българския език към Института за български език при БАН с Румънската академия на науките на тема „The diastratic variation in the historical vocabulary of Bulgarian and Romanian“ („Диастратичното вариране в историческия речник на българския и румънския език“), 2018-2019 г. 
деленото от среднородопския религиозен и просветен деец поп Марин Караджов от Чепеларе, Рупчоско: „Аз сам са родил в 1840 на 4-и марта. Като сам станал 6-7 г. зафанал сам да следувам в училище и до 9-10 година сам можел да науче тогавашните учебни буквар Славя[н]ски (Еленски) Октоих, Псалтир и Апостол и да писувам имена и цифри (Потребно е да кажим, чи тогава бе сичкото по гръчки, четюву, писване, сметане). Ей! От тука нагоре нема какво да учи, казуваха учителете. Сига требова да са учи язик! Затова баща ми завида ма нах Ташюс [остров Тасос в близост до гр. Кавала на Бяло море - бел. мои, Г.М.] да са уче терзие и гръчки язик“ (Ваклинова/Vaklinova 1972, 212).

През периода 1834-1836 г., след издействани султански фермани от страна на среднородопските български християнски села, е разрешено да се построят църкви. За един кратък период до 70-те години на XIX в. в Среднородопието са построени 26 църкви (Гиневски/Ginevski 2008, 101). В новопостроените християнски храмове още от 30-те години на XIX в. се служи на гръцки език чак до 60-те и 70-те години на XIX в., когато среднородопските християни се включват активно в борбата за църковна независимост и успяват да издействат в повечето местни църкви службите да се извършват на разбираем за тях църковнославянски език, а не на гръцки. За положението в Югоизточните Родопи, по-точно на българските християнски села в Западна Тракия, е показателен един цитат от биографичната книга на Хр. Попконстантинов, посветена на капитан Петко войвода, родом от с. Доган Хисар, Дедеагачко: „Когато станал Петко на 15 години, не слушал баща си и започнал да ходи в селския метох да се учи да чете и пише. В училището той се отличавал със сериозност и внимание в работата му и до 17-годишната си възраст той се научил да прочита гръцки думи и да пише с гръцки букви български думи, като в онова време по южните и източните поли на Родопите новобългарския язик и новобългарското писмо не бяха въведени, а старославянското писмо бе съвършено изчезнало. Това било в 1861 г., когато във всичките родопски християнски села гръцкия език пееха в черквите и учеха в училищата“ (Попконстантинов/Popkonstantinov 1885, 9).

В случая езиковата ситуация в Среднородопието и в Западна Тракия в средата на XIX в. не се различава от ситуацията в други краища на българското езиково землище. Например Й. Груев в описанието на езиковата ситуация в Пловдив в средата на XIX в. отбелязва, че гръцкият език господства в града, а български се употребява само в предградията Мараша, Каршияка, Нова махала (Груев/Gruev 1906, 4, 14). Ситуацията в Македония е сходна. По сведения на Ст. Веркович от 1860 г. местните български занаятчии са принудени от обстоятелствата да усвояват и да общуват на гръцки език, което е свързано с препитанието им (ВП/VP 1992, 205).

Подобно силно гръцко влияние има и във Влашко и Молдова през XVIII в. При наложеното фанариотско управление в двете княжества от страна на Османската империя официални езици там са румънски, гръцки и български. Елинизацията е факт още в началото на века, за което съдим по запазени ръкописни писмени паметници в български и чужди архивохранилища: ръкописен сборник с молитви от Барбу Хобан, съхраняван в шуменското читалище „Добри Войников“ с датировка от 1704 г., написан на трите споменати езика 
(Стефанов/Stefanov 2009, 240-252); Кондика на гръцката търговска компания в Брашов от края на XVII и началото на XVIII в. (Маслев/Maslev 1988, 93) и др. Според чужди пътешественици през 1702 г. трите езика са еднакво легитимни в литургиката, литературата и княжеската канцелария от православните румънци (АПБ/АРВ 1987, 287).

Началото на възраждането на среднородопските българи християни е свързано с дейността на йеромонах Григорий, който като таксидиот на Ватопедския манастир в Атон посещава за пръв пьт краището през 1838 г. Ситуацията тогава е твърде неблагоприятна за църковна и просветна дейност. Няма запазени следи от стари писмени традиции в Среднородопието. Тепърва създаващите се големи български просветни центрове като Пловдив, Одрин, Солун са твърде отдалечени от Среднородопието. Освен това планината е опасана от гъркомански центрове, каквито са гр. Ксанти и Гюмюрджина от юг, Станимака (дн. Асеновград), Хасково, Пещера, Бачковския манастир от север. Като се прибави и наличието преимуществено на българско население, изповядващо мюсюлманска религия, чуждо на стремежите на българите християни за икономическо, културно и просветно издигане, видно е, че няма предпоставки за начало на възраждане в Среднородопието.

Първоначално йеромонах Григорий е посрещнат хладно от местните християни поради незнаенето от негова страна на български език. Макар да има хипотези, че е българин, родом от с. Загоричани, Костурско, надделява мнението, че е бил грък и впоследствие научава български език (местното родопско наречие) (Маринов/Marinov 1978a, 22-24; 1978б, 36-38). По негова инициатива в местните църкви богослужението се извършва не на гръцки, а на разбираем за населението български език. Монахът е инициатор за създаването на дамаскинска книжнина, като изгражда своеобразна местна среднородопска дамаскинарска школа. Под негово ръководство се създава препис на дамаскински сборник в превод от гръцки език на местен родопски диалект. Впоследствие подготвени от него местни свещеници осъществяват още преписи на дамаскински текстове с активна негова помощ. Така възниква Устовският дамаскин, чийто автор е първият последовател на поп Глигорко в Среднородопието, местният свещеник Киряк Бялковски. Впоследствие са направени преписи от свещениците в по-големите християнски селища в района. Запазен е частичен препис на Петковския дамаскин, чийто създател е местният свещеник поп Костадин Манолюв (Попконстантинов/Popkonstantinov $1888,133-156 ; 1889,269-284)$. За съжаление, от многобройните дамаскински преписи до днес е оцелял в оригиналния си вид само преписьт от с. Райково, благодарение на това, че в Долно Райково гъркоманството е имало силни позиции и местният български книжовник гъркоман Георги Радев е съхранил писмения паметник в личния си архив (Стоянов/Stoyanov 1972, 229; Митринов/Mitrinov 2005, 21).

През този период се създават и учебни помагала. Малка част от текстовете на Райковския дамаскин, датиран от 1859 г., включват примерни текстове на документ за даване пари назаем, таблица за умножение и др. Те са с по-късна датировка - 1869 г., и са добавени впоследствие (Митринов/Mitrinov 2005, 33). Учебно помагало се явява Златоградският сборник, датиран от 1852 г., 
който включва писмовник с примерни текстове на писма и текстове от Ветхия завет на Библията (книги Премъдрост Соломонова и Притчи Соломонови). Характерно за него е, че е двуезичен. Текстовете са на гръцки и съответно на български език с гръцка графика, като на всяка срещуположна страница успоредно с гръцкия текст е даден и негов превод на български (Митринов/ Mitrinov 2000).

\section{2. За спецификата на среднородопската възрожденска книжнина}

Важно е да се отбележи, че дамаскинските преписи и учебните помагала са писани на разговорен български език (местен родопски говор) с гръцка графика. През първата половина и в началото на втората половина на XIX в. основна е употребата на гръцка графика в писмената практика на среднородопските българи християни. Те изписват имената си с нея. Дори личните им печати са оформени преимуществено с гръцка графика.

Среднородопските дамаскини от средата и втората половина на XIX в. са късни дамаскини. Характерна тяхна особеност е, че езикът им е много близък до разговорния български език (в случая местните български говори). Това е свързано с предназначението им да бъдат лесни за възприемане от обикновените българи - четци и слушатели. Текстовете са изпъстрени с лексика от чужд (основно османотурски и гръцки) произход, характерна за местните говори. Употребените непознати думи, свързани с църковна терминология и др., са пояснени, вероятно с цел да бъдат разбираеми за ползвателите на сборника. Това в голяма степен важи и за учебните помагала, чийто език също е близък до разговорния (местния диалект), а включените непознати думи се поясняват с думи от местния говор.

Не става ясно дали местните книжовници са използвали първоизточник, който е бил на български език с грьцка графика. Но е факт, че в първата част на Златоградския сборник, съдържаща примерни текстове на писма, ойконимията в изписаните адреси е свързана с търговската дейност и с гурбетчийството на местните българи християни. Така най-много писма са адресирани до селищата Гимуржина (Гюмюрджина, дн. грц. Комотини) и Даритере (дн. Златоград), по-малко - до Филбе (дн. Пловдив), а отделни писма - до Правуща (Правища), Кавала, Йенидже (дн. грц. Генисеа); Стамбол, махала Гюмрук (дн. Истанбул); Исмир (дн. Измир). Доста от писмата са адресирани до свещеници в църкви на съответните селища Филбе, Гимуржина, Мароня, както и до игумена на манастира Ватопед в Света гора. Все пак може да се предположи, че текстовете на Писмовника, ако са били превеждани от гръцки първоизточник, може да са били актуализирани, като селищните имена са били заменени с такива, които са били познати на тогавашните жители на Дарьдере.

Диастратичният подход в настоящото изследване дава възможност да се видят начините, които използват книжовниците, за включване в създадените от тях писмени паметници на лексика, нехарактерна за местния говор. Така може да се оформи картината на заемане на такъв тип лексика. Като цяло въпросът за избор на предпочитана лексика, главно свързана с църков- 
на терминология, показва пътищата, по които този тип лексика се озовава в среднородопските възрожденски писмени паметници. Едва ли може да се говори за целенасочена употреба на църковнославянизми, които да заменят турцизмите и гърцизмите в разговорната реч, но е виден стремежът на местните книжовници да създават разбираеми за местното българоезично население текстове. Да, текстовете като цяло са писани на български родопски диалект. Но може да се предположи, че в първоизточниците, от които е превеждано, е имало терминологична лексика без свои съответствия в тези български говори. За целта терминологичната лексика е била пояснявана с добавени общоупотребими гръцки и османотурски заемки в местните български говори. По този начин, чрез текстовете на едно учебно помагало, каквото се явява Златоградският сборник, както и чрез дамаскинските текстове, се правят първи опити да се включва лексика от домашен, български произход в текстове за обучение на местните ученици и за ограмотяване на възрастните. Но е факт, че в Райковския дамаскин се открива и синонимия, включваща думи само от чужд произход или само от български произход. Вероятно целта е била да стане текстьт по-разбираем за обикновения местен българин.

Предмет на настоящото изследване е проучване на спецификата на поясняване на включената в текстовете на среднородопските възрожденски писмени паметници терминологична лексика. Целта е да се види общото и различното в подходите, използвани в двата типа писмени паметници - дамаскински текстове и учебни помагала.

Както бе отбелязано по-горе, налице е успоредна употреба на лексика, нехарактерна за местните български говори, от чужд и от домашен, български произход, наред с такава, битуваща в говорите. Става въпрос основно за терминология, свързана с църковното богослужение, както и за термини от други сфери на обществения живот. Така чрез диастратичния подход при разглеждане на спецификата на употребената лексика в среднородопските възрожденски писмени паметници може да се представи по-пълна картина на използвания речников инвентар от местните книжовници, а и да се види какви са тенденциите в употребата му.

В учебното помагало ,Златоградски сборник“ думите, които писачите са преценили, че са неразбираеми за ползвателите му, вероятно ученици в местното училище, са пояснени със задпоставени думи, използвани в местния говор, оградени в кръгли скоби:

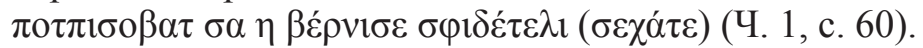

Спорадично е добавянето на поясняващата дума, без да е оградена в кръгли скоби:

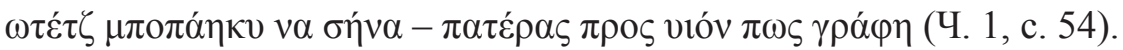

В дамаскинските текстове преобладава изписване на задпоставената поясняваща дума, характерна за местния български говор, независимо дали е чужда заемка, или не, без да е оградена в кръгли скоби:

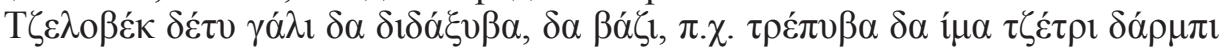

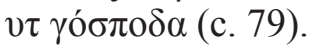

Само в няколко случая е налице изписване в кръгли скоби: 


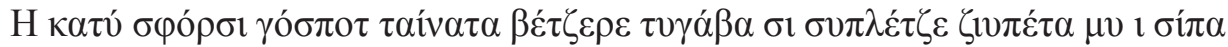

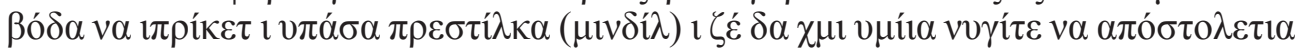
(c. 248).

Като цяло подходът при поясняването на употребените непознати думи и изрази в дамаскинските текстове е по-различен. В тях понякога това е направено описателно, което е свързано и с предназначението на сборниците: да бъдат четени пред групи хора, на разбираем за тях език:

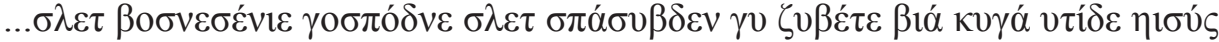

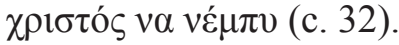

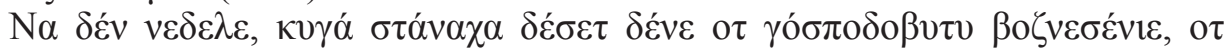
$\sigma \pi \alpha ́ \sigma \nu \beta \delta \varepsilon v$... (c. 32).

воснесѐние госпо̀дне / го̀сподову вознесѐние - спа̀сувден

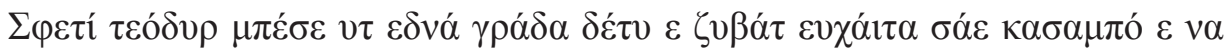

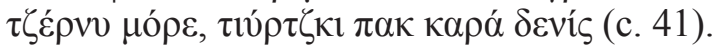

Чѐрну мòpe - Кара̀ денùc

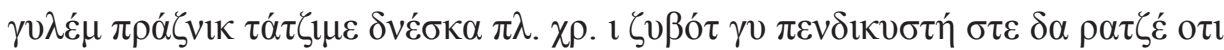
$v \tau \beta \varepsilon \lambda \dot{\delta} \delta \varepsilon v \delta v \delta v \varepsilon \dot{\sigma} \sigma \alpha \sigma \alpha \pi \varepsilon \delta \varepsilon \sigma \varepsilon \dot{\varepsilon} \delta \varepsilon ́ v \varepsilon$ (c. 155).

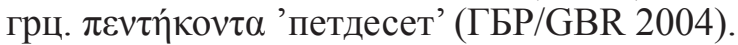

пендикустй - педесѐ дѐне (петдесетница)

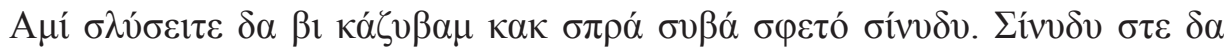
$\rho \varepsilon \tau \zeta \dot{\varepsilon} \sigma \pi \imath \rho \operatorname{\beta u\alpha }$ (c. 224).

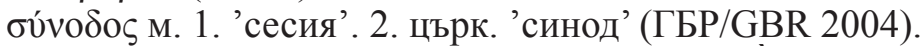

блıро́ßıа збиро̀вийа с. 'сборище', срв. збироิ̀ ж., збйрица ж. ум. 'разни дребни неща, подарък' (Славеино, Виево, Кутела, Смолянско, Ардинско, Маданско) (Стойчев/Stoychev 1965); збиро̀виште с. 1. 'място, дето се спират и събират хора'. 2. 'място, дето се събира селският добитьк и откъдето се отправя на паша' (Дорково, Велинградско) (Стойчев/Stoychev 1970); збйротина ж. 1. 'множество различни хора'. 2. 'много и най-различни неща на едно място' - селата в района на с. Кирково, Момчилградско (Стойчев/Stoychev 1983).

сѝнуду - спиро̀вийа

В други случаи са преведени на български език цели изрази, изписани на гръцки език, включени в текста:

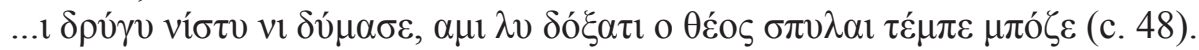

$\delta$ ó $\xi \alpha \tau \imath$ о $\theta \dot{\varepsilon}$ о $-\delta$ о $\xi \alpha \sigma i ́ \alpha-\tau \omega \theta \varepsilon \omega$ 'слава богу' (ГБР/GBR 2004).

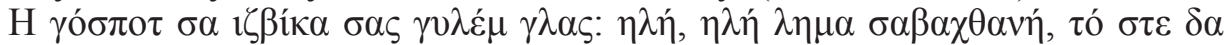

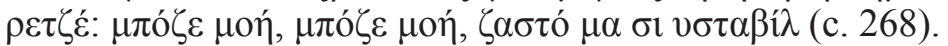

В дамаскинската книжнина се натькваме и на включване в текстовете на думи и изрази от друг език, главно грьцки, които не са пояснени или преведени. Вероятно преводачите са се затруднили да ги преведат:

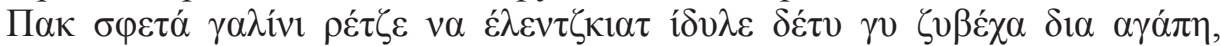

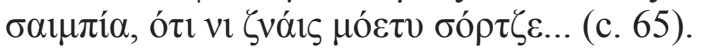




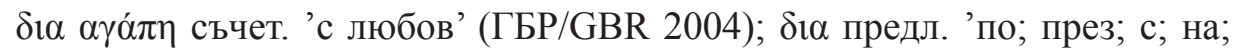
заради, за' (ГБР/GBR 2004). (c. 83).

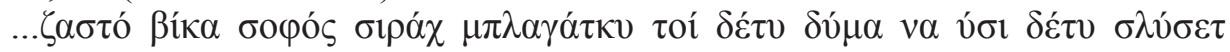
бофо́ м. 'мъдър, учен', в случая 'мъдрец' (ГБР/GBR 2004).

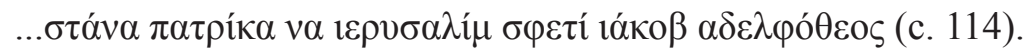

. $\alpha \delta \varepsilon \lambda \varphi o ́ \varsigma$ 'брат'; $\theta \varepsilon о \varsigma$ 'бог' (ГБР/GBR 2004), т.е. 'брат на бога, божи брат'.

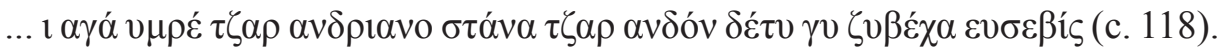

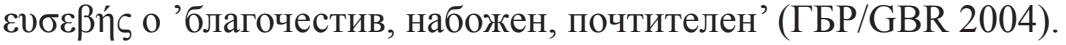

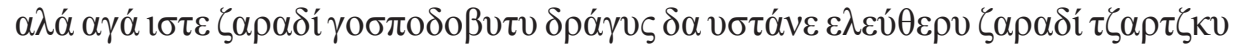

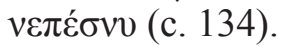

$\varepsilon \lambda \varepsilon v ́ \theta \varepsilon \rho о \varsigma$ о 'свободен, волен, независим' (ГБР/GBR 2004).

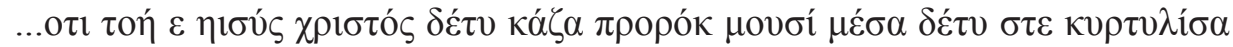

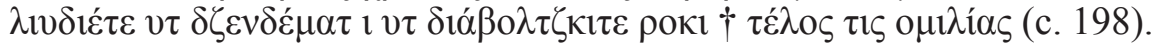

край на проповедта 2004).

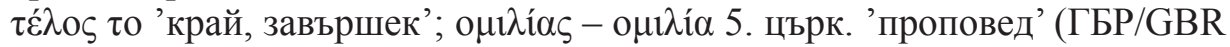

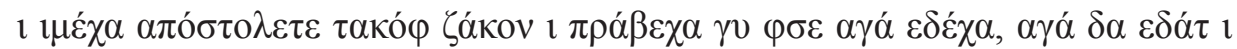

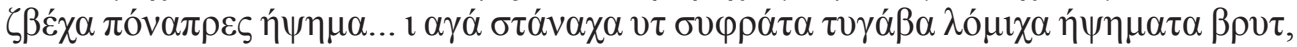

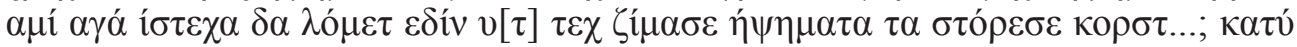

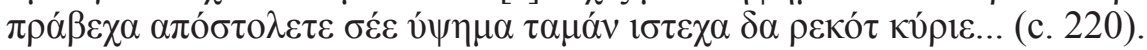

ѝпсома 'нафора' (Гоце Делчев; Солунско); йпсимо с. 'нафора, натопена в комка и сложена в дънера на високо и дебело дърво - дар на дух за плодородие' (Яврово, Асеновградско) - от грц. v́ $\omega \mu \alpha$ 'нафора' (БЕР/BER 1979).

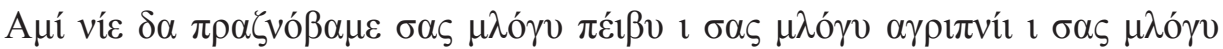

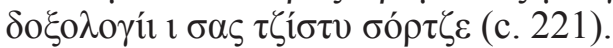

$\alpha \gamma \rho v \pi v i ́ \alpha ; ~ \alpha \gamma \rho v ́ \pi v 1 \alpha$ 1. 'безсъние, бдение'. 2. църк. 'всенощно бдение'

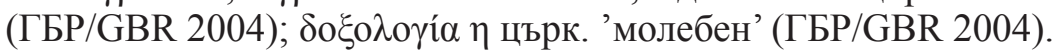

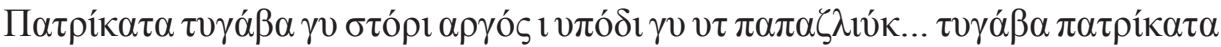

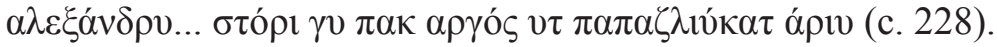

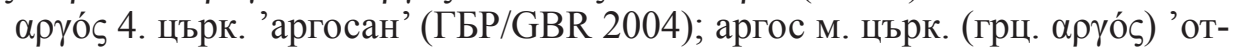
немане на свещеник правото да служи' (PPOДД/RRODD 1974).

$\pi \alpha \pi \alpha \zeta \lambda$ vóк тур. papazlık 'дльжност на свещеник, свещеничество, попство' (ТБР/TВR 1962).

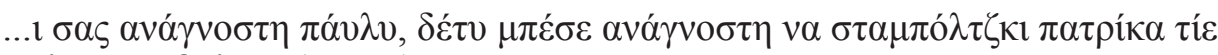

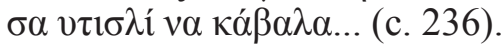

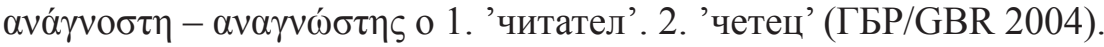




\section{3. Специфика на поясняване на терминологична и нетерминологична лексика в среднородопските възрожденски писмени паметници}

Проявите на пуризъм, т.е. опитите за включване на лексика от домашен, български произход в среднородопските възрожденски текстове, се изразяват в успоредна употреба на такава лексика, засвидетелствана в църковнославянски писмени паметници или в по-стари писмени източници, наред с битуващи в местните родопски говори гръцки и османотурски заемки. Обикновено първо е изписана употребената нова дума, след което е добавен неин синоним, характерен за местния говор, за да я поясни. Но се случва, макар и по-рядко, изписването да е и в обратен ред. Синонимията включва също употреба на двойки и повече думи от чужд произход (гръцки и турски), както и синонимни двойки от домашен, български произход. Както бе отбелязано по-горе, в случая едва ли може да се приеме, че е налице целенасочена дейност на местните книжовници, сътворили писмените паметници, с цел да се премахнат от езика на обикновените местни българи множеството турцизми и гърцизми. По-скоро това е опит да се обяснят употребените непознати за носителите на местните български говори думи от български произход при преписването и превеждането на текстовете. Целта е била да са разбираеми те за читателите и слушателите.

\section{1. Поясняване на думи в Райковския дамаскин}

Поясняване на думи в Райковския дамаскин, което включва успоредна употреба на лексика от домашен произход, засвидетелствана в църковнославянски писмени паметници, с битуващи в местните говори чужди заемки, главно гръцки.

\section{УЧИТЕЛ - ДАСКАЛ}

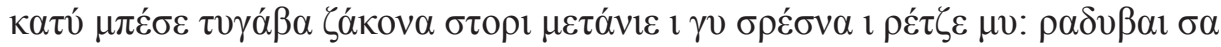
$v \tau \zeta i ́ \tau \varepsilon \lambda v, \delta \alpha ́ \sigma \kappa \alpha \lambda \varepsilon v \alpha ́ \sigma ı$ (c. 241).

учител м., стб. оччитель (CP/SR 2009); цслв. оччитель церкви = такъ называются богомудрые мужи первых веков християнства (Дяченко/Dyachenko 1900); оучитель м. 207, 210, 214, 256, 269, 289, 367 (Троян. дам.) (Иванова/ Ivanova 1967).

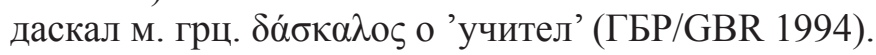

ПРАЗНИК - ПАНАГИР

Обичайно думата от домашен, български произход празник е изписана първа, а гръцката заемка, битуваща в местните говори, е следходна и я пояснява:

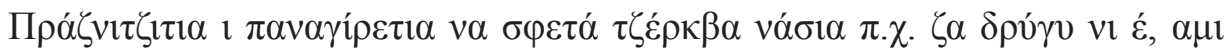

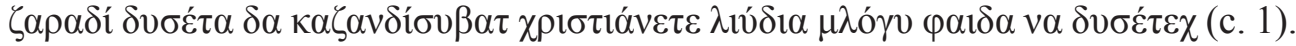

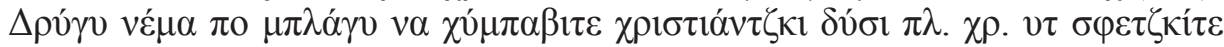

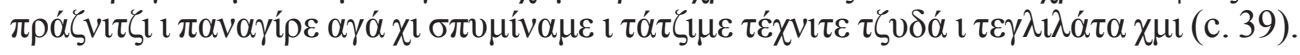




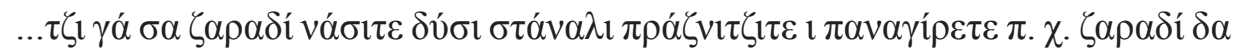

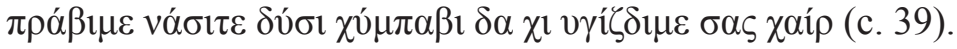

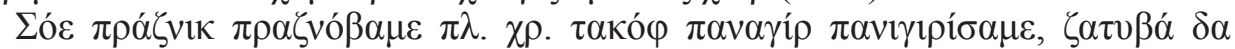

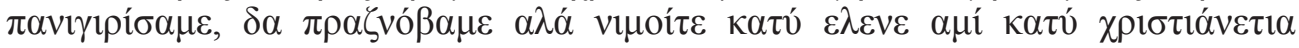
(c. 221).

В единичен случай гръцката заемка е изписана пред думата от домашен, български произход:

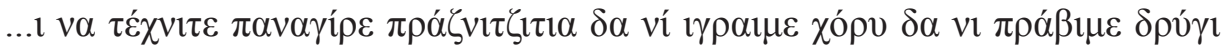

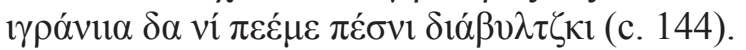

празник м. стб. праъ,Анникъ м. 'празник, установен от религията и тра-

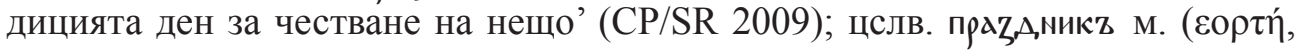
$\pi \alpha v \eta ́ \gamma v \rho ı \varsigma)$ 'торжественое собрание, торжество' (Дяченко/Dyachenko 1900); цслв. прдъ,ммлювєцZ м. 'който почита празниците, установени от Цьрквата' (Бончев/Bonchev 1995); праздник, празник м. 1. 'празник; тържествен ден, в който се чества събитие от християнската история'. пра̀здныцїи и събо́ре црковнїи блсвенїи хрстїане зарадь другга ра̀бота не бывать... 39.295. (РКБЕНО/RKBENO 2012); праздникъ м. 29, 30, 77, 116, 182, 294, 313, 354 и др. (Троян. дам.) (Иванова/Ivanova 1967).

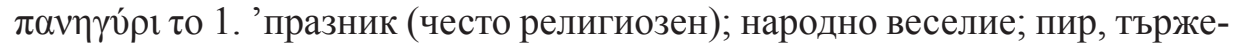
ство; веселие'. 2. 'панаир'. 3. 'пазар' (ГБР/GBR 2004).

панагѝр (грц.) м. остар. 'панаир' (Смолянско, Ардинско, Асеновградско, Маданско, Девинско) (Стойчев/Stoychev 1965).

Успоредна употреба на двете лексеми се открива и в Тихонравовия дамаскин: празник м. 1. 'празник, тържествен ден, в който се чества събитие от християнската история'; панагир м. 'панаир, събор, празник': ...и бжствны ду̀ми да послу̀шамѐ замь да прїемнем добро̀ $\widetilde{w}$ того̀зи стца̀ дето го пра̀зднуваме та сѝ о́став'ьме сѝчька рабо̀та ато́ му ѝмаме пра̀здникь вь то̀йзи день и панагүрь... 39.295б (РКБЕНО/RKВENO 2012). Може да се предположи, че в късните среднородопски дамаскински преписи от средата на XIX в. е заимствана една традиция, установена в дамаскините от по-ранни периоди (XVII в.).

\section{ПРАЗНОВАМ - ПАНИГИРИСАМ}

В текстовете на Райковския дамаскин се открива успоредна употреба на производни глаголи празновам и панагирисам / панигирисувам, които не са засвидетелствани в посочените облици в църковнославянски писмени паметници и в други дамаскински преписи.

От засвидетелстваните 4 употреби на синонимната двойка в два случая първо е изписана глаголната форма празноваме и в два - панигирисаме.

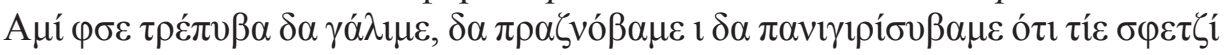

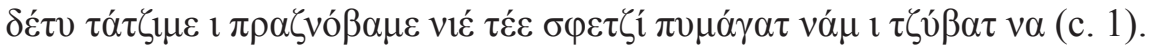

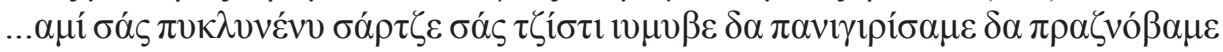
$\zeta \alpha \sigma \varphi \varepsilon \tau \alpha \dot{\alpha} v \varepsilon \delta \varepsilon \dot{\lambda} \varepsilon$ (c. 144).

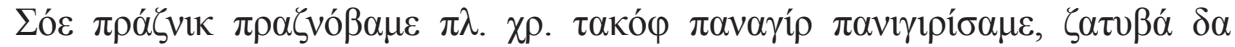

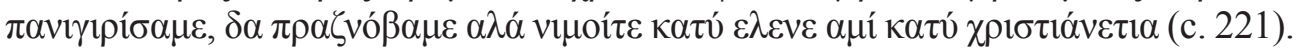


празновам несв. 'празнувам', стб. прдъ,Аьмовати 3. 'празнувам, чествам празник, ликувам' (CP/SR 2009); празднувам несв. 'празнувам, чествам някакъв празник'. и с‘ькыи члкь е дльжьнь да пра̀зднува ѝ да почѝта црьскыи праздникь... 33.232б. (РКБЕНО/RKВЕNО 2012); празднувашь (Троян. дам.) (Иванова/Ivanova 1967).

$\pi \alpha v \eta \gamma v \rho i ́ \zeta \omega$ 1. 'празнувам, чествам, тържествувам'. 2. 'пирувам, веселя cе' (ГБР/GBR 2004).

Bсе пак трябва да се отбележи, че обликът празно̀вам има диалектен характер. Глаголното словообразуване с наставка -овам е характерно за рупските говори (Бояджиев/Boyadjiev 1991, 85), част от които са родопските (купо̀вам, даро̀вам, мино̀вам и др.).

\section{ЗАШТО (ЗАЩОТО) - ОТИ}

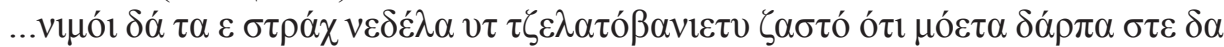
$\varepsilon \sigma \alpha \varsigma \tau \varepsilon \dot{\varepsilon} \mu \pi \mathrm{i} \ldots .$. (с. 140).

оти 'защо', 'защото, понеже, че' оти (Банишко четириевангелие XIII в.) от грц. оли 'че' (БЕР/BER 1995).

и метна̀ха рьч на нѐго: о́ти ґдѐшь и кр(ъ)стйл си, и да не съдѝшь вѐкю на сто̀ль защо̀ ти не подоба̀е (Троян дам. 151) (Иванова/Ivanova 1967).

зашто нареч. защото; чслв. зачьто = для чего (Дяченко/Dyachenko 1900).

Интерес представлява употребата на синонимната двойка зашто - оти, още повече че е засвидетелствана в единичен случай. В бележки под линия към нормализирания текст на Петковския дамаскин Хр. Попконстантинов е отбелязал: Вл[ияние] отъ Неоф[итовото] Евангелие. Тукъ защо е написано вмњсто оти. (...и сасъ сичку соарце защо нидеалйата даде Госпуть...) (Попконстантинов/Popkonstantinov 1889, 145).

Първата съставка зашто не е характерна за местните родопски говори в употреба като относително наречие със значение 'защото'. От друга страна, в текстовете на Тихонравовия дамаскин се открива същата синонимна двойка, представена като сложен съюз в речниковата статия защо нареч., нареч.-съюзна дума, съюз.

защо IV Съюз. 1. Въвежда подчинени допълнителни изречения; че. 3. Въвежда подчинени обстоятелствени изречения за следствие; тъй че, та. защо оти Въвежда подчинени обстоятелствени изречения за причина; защо-

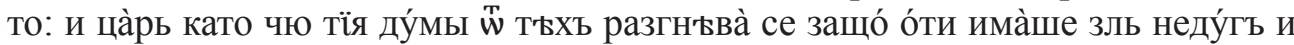
бо́лесть люта 1076б; амù и вые сѝчки езыци що стѐ въ а̀дъ да̀ се зарадувате... защо. о́ти ѝде спасѐнїе. и спсь прихо́ди да вы ѝзвади 35.258; оти защо Въвежда подчинени обстоятелствени изречения за причина; защото: а̀ми защо́ го прњда̀де. о́ти защо бъше зло́ у́менъ и дїа̀волъ 35.262; сты будъте сѝчкы. о́ти, защо сьмь азъ сть 38. 294 и др. (РКБЕНО/RKBЕNO 2012). Отбелязана е употреба и на сложен съюз оти защо да с две функции: а) Въвежда подчинени обстоятелствени изречения за цел; за да. и по въскрсѐние ґде медь съсь вощу́на. во́ськъ о́ти, защо да просвъти ада̀ма и сùчкыте что съ изъ ада̀ма. 38.289. б) Въвежда подчинени обстоятелствени изречения за следствие; за да, та да. амѝ послу́шайте съсѝчк (!) срдце. да разберѐте за стго нико́лае и дру́гыте му чюдеса о́ти, защо да просла̀вите бога и да похва̀лите стѓ́ 15.1426 (РКБЕНО/ 
RKBENO 2012). Важно е да се отбележи, че в някои примери двете наречия са разделени с препинателен знак запетая или точка, колкото и относителна да е употребата на препинателни знаци в дамаскинските текстове.

В случая, ако се приеме, че това е сложен съюз, не става ясно каква е спецификата му в сравнение със самостоятелната употреба на съюзи оти и зашто в дамаскинските текстове. От друга страна, може да се предположи наличие на приемственост в употребата на сложен съюз защз оти, чиято първа съставка е от български произход, а втората - от гръцки, в Райковския дамаскин, тъй като такава употреба е засвидетелствана в по-ранни български дамаскини от XVIII в., какъвто се явява Тихомировият дамаскин. Липсата на по-обширен илюстративен материал не дава възможност да се правят по-конкретни изводи.

Среща се и друго мнение за употребата и за спецификата на сложния съюз защзо оти в дамаскинската книжнина. Според някои изследователи в новобългарските дамаскини заради изискването за достыпност на изказа често се откриват дублирани съюзни връзки, изградени от два елемента с почти синонимно значение, които едновременно изразяват синтактичното отношение. Например: подчинено изречение за цел се въвежда от оти защо да и оти зан да; подчинено изречение за причина може да бъде свързано с двойните съюзи защо оти, оти защо, заради защо; а в началото на подчинено допълнително изречение се среща оти как (Мичева/Micheva 2018, 229).

В някои случаи употребен църковен термин от гръцки произход в текста е пояснен с общоупотребима дума от домашен, български произход, включена с тясно значение.

\section{ПЕЯ - ПСАЛМУВАМ / ПСАЛНУВАМ}

В два примера имперфектни форми на глагол пея за 3 л., ед. и мн.ч. са изписани пред съответните форми на глагол пса̀лнувам:

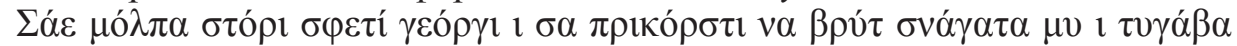

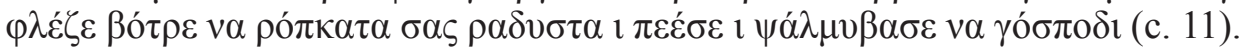

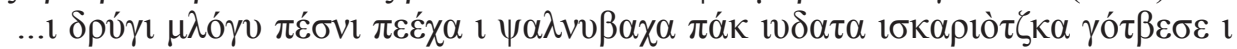

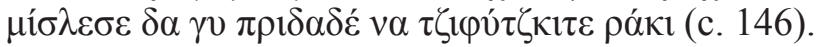

В други два примера формите на глагола пса̀лнувам са изписани пред тези на глагола пея. Дори във втория пример е налице удвоена употреба на глагола:

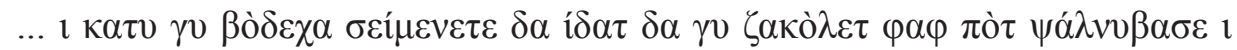

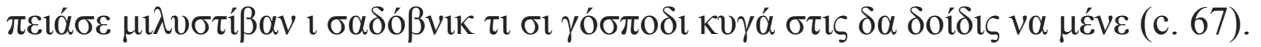

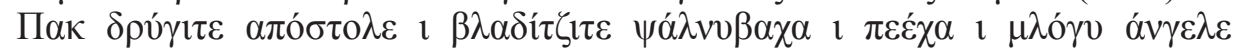

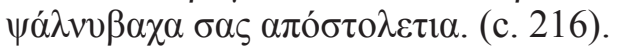

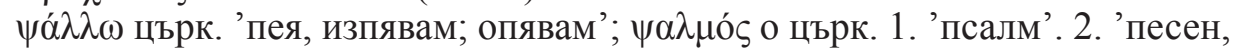
химн, ода' (ГБР/GBR 2004);

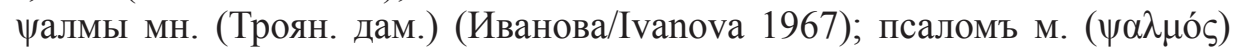
'пяснь, пяснопяние', но в речниковата статия на няколко места е изписан глагол ча́ $\lambda \lambda \omega$ 'пея' (Дяченко/Dуachenko 1900); стб. псдлъмz м. 'псалм, песен от състава на Псалтира, псалом' (CP/SR 2009); фалдти 'пея, опявам в църква' (Miklosich, Lex PSI 1169) (БEP/BER 1996). 
пея несв. 'пея, изпълнявам черковни псалми' (РКБЕНО/RKBENO 2012); пґяешь гл. 1. 'пея', 3 л., ед.ч. 2. 'пея, изпълнявам черковни псалми'. 189 (Троян. дам.) (Иванова/Ivanova 1967).

В други примери употребената дума, засвидетелствана и в църковнославянски писмени паметници, е пояснена с битуваща в местните български говори гръцка заемка:

\section{ЛОШ - Н’УФЕЛИТ (НЕФЕЛИТ)}

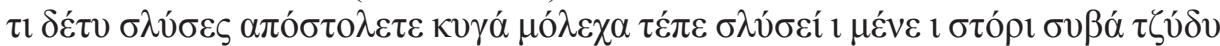

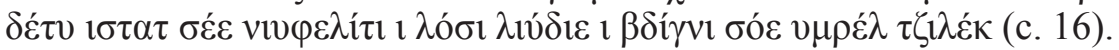

нефелйт прил. 'лош' (Смолянско, Ардинско, Асеновградско, Маданско);

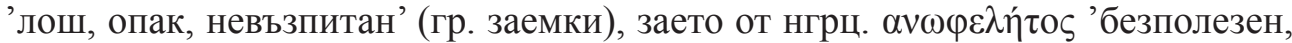
вреден', като нгрц. av. е калкирано с бълг. не (БЕР/BER 1995);

нефелит прил. 'нефелит, немощен, болнав'; нефелитец м. 'негодник, лице, което е непочтено, лошо'. ́́ нефелитьче и непочьтѐнниче то́й съка че ще да дрьжй црството си за мнб́го à не зна̀е (РКБЕНО/RKВЕNO 2012);

нефѐльный прил. ...що съм възмо̀жьнь а̀зь нефѐлный чл(овъ)кь таквь̀ (Троян. дам. 32) (Иванова/Ivanova 1967).

лош прил. 'лош, чиито качества не са добри'. и юного́зи купьца̀ ца̀рьскыго члка посадѝха на почьте́но мъсто а •.ома на кр(а)ù на по́лошо м'сто. 7.50. (РКБЕНО/RKВENO 2012);

лош прил. цслв. Аошь 'дешевый, плохой' (Дяченко/Dyachenko 1900).

Налице е успоредна употреба на думи от домашен, български произход, характерни за църковнославянския език, и на турцизми, битуващи в местните български говори.

\section{ГРАД (ГРАДА) - КАСАБО (КАСАБА)}

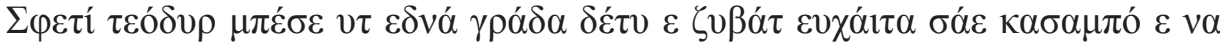

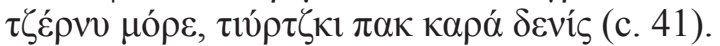

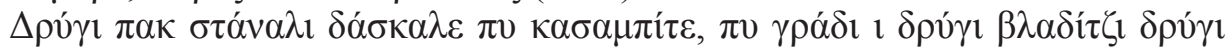

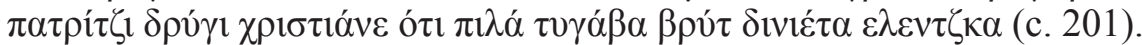

Откриват се примери, в които няма изписване на синонимите непосредствено един след друг, а в пасаж от текста е налице разнообразие в употребата им, от което е видно колебанието на писача (писачите) коя дума да се избере:

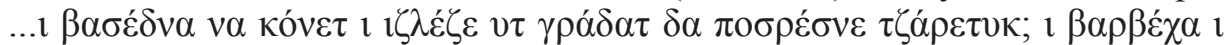

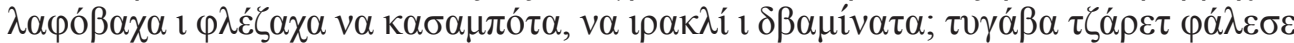

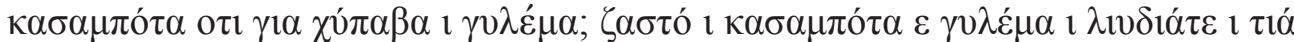

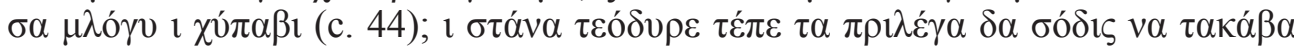

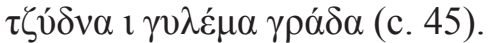

Видно е колебанието на преписвачите (преводачите) и при определяне на рода на употребената лексема град, като от 4 употреби в три случая тя е представена в ж.р., може би под влияние на битуващия в местните български говори турцизьм касабо, който също е от ж.р.

В бележки под линия към текста на Петковския дамаскин Хр. Попконстантинов отбелязва: Градит в вм. градовет ъ. Вл[ияние] отъ Н[еофитовото] 
Е[вангелие]. (...оти кату гльоада пу врить діуньоата, пу врить градить, пу врить касабить...) (Попконстантинов/Popkonstantinov 1889, 148).

касаба ж. 'мальк град, градче, градец' (DTB 2002); kasaba 'малък град, градец, градче' (ТБР/TBR 1962).

град - стб. гра,д, z м. 'град, голямо населено място' (CP/SR 1999); гра,А, z = городъ (Дяченко/Dyachenko 1900).

град м. 1. 'град, голямо населено място, голямо селище' (РКБЕНО/ RKBENO 2012); градь м. ...защо̀ а̀зь щѐмь да хо́дим от градь на градь да ка̀зувам да върувать (Троян. дам. 66) (Иванова/Ivanova 1967).

\section{ЧАС - САХАТ / САХАТ - ЧЕС (ЧАС)}

В текст от несъщинската част на сборника се открива успоредна употреба на двата синонима, като турцизмът caxam, битуващ в местните български говори, е изписан след думата от домашен, български произход и е поставен в крьгли скоби:

$\pi \alpha \dot{\kappa} \mu 1 \lambda v \sigma \tau \imath \beta v \alpha$ ví $\varepsilon \mu i ́ \lambda v \delta \alpha \delta \alpha \delta \varepsilon ́ \mu \varepsilon$ ó $\tau 1 \sigma \tau \varepsilon \delta \alpha \delta$ óı $\delta \varepsilon \tau \zeta \alpha \varsigma(\sigma \alpha \chi \alpha \tau) \sigma \tau \rho \alpha ́ \sigma \varepsilon v, \tau \alpha$

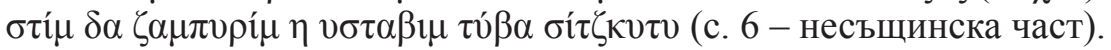

В другите два примера първо е изписана турската заемка в местните български говори, след което е включена и лексема час в облик чес:

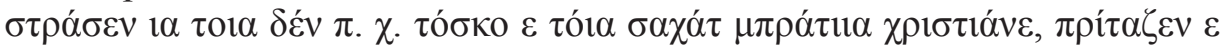
$\tau$

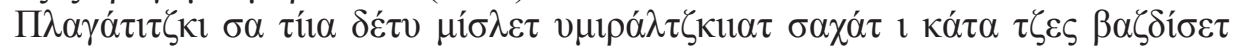

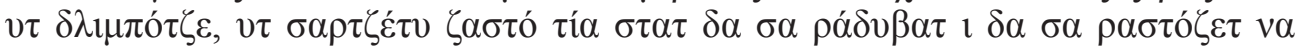

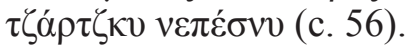

сахат, тур. saat 'час' (ТБР/TBR 1962).

час м. 1. 'час, единица мярка за време'. 2. 'час, определен момент от денонощието или времето изобщо'. 3. 'време изобщо'; тоя час 1. 'по това време'. 2. 'на часа веднага'; ката ден ката час 'постоянно, непрекъснато' (РКБЕНО/ RKBENO 2012); а ты помыслй го̀рькыте мы̀кы. помыслй стра̀шны час съмрьтни (с. 18). ...погуубиль бы нас сйчькы вь едйнь час (с. 15) (Троян. дам. 18, 15) (Иванова/Ivanova 1967).

\section{ЗАПЕЧЕТЕН - МЮХЮРЛЕДИСАН}

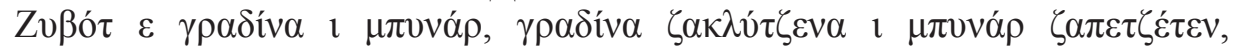
$\mu$ $\chi 10 \rho \lambda \varepsilon \delta i ́ \sigma \alpha v$ (c. 207).

запечетен прил. - от цслв. дапєчдтхьтт 'полагать печать'; запечатляние zдпєчатлғкиє с. 'печать' (Дяченко/Dyachenko 1900); запечатиха м. св. (Троян. дам.) (Иванова/Ivanova 1967, 247-394).

мюхюрледисан - от тур. мюхюр mühür м. 'печат (металически); печат'; 'отпечатьк на печат'; mühürlemek 1. 'подпечатвам, удрям печат'. 2. 'запечатвам с червен восък' (ТБР/TBR 1962).

Интерес представлява високата честотност на употреба в текстовете на отделни лексеми, характерни за местния български говор, поясняващи в повече от един пример различни думи от домашен или от чужд произход, с които са в синонимна връзка. Така се оформят цели синонимни редове. В си- 
нонимния ред хората̀ - ду̀ма - реч - збор - сло̀во - лаф доминантен синоним се явява гръцката заемка хората̀.

\section{ХОРАТА - ДУМА, РЕЧ, ЛАФ, ЗБОР, СЛОВО}

В повечето случаи с гръцката заемка в местните български говори се пояснява дума, характерна за книжовния език:

\section{ДУМА - ХОРАТА}

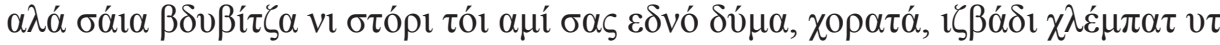

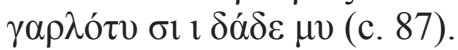

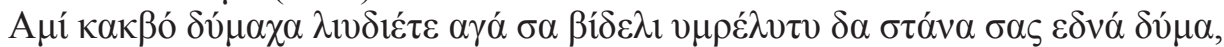

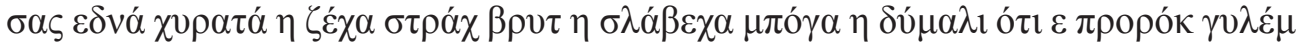

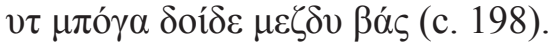
не'.

Синонимите са употребени със значение 'дума, говор, устна реч, говоре-

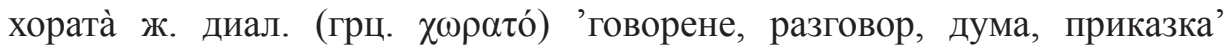

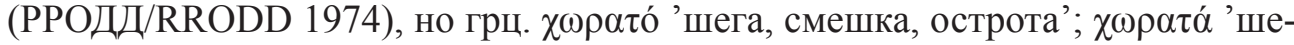
гувайки се, на шега' (ГБР/GBR 2004); хората ж. 'говор, приказване на висок глас, врява, хората'. и по пь̀тищата гль̀чка и хората̀ мно́го и вѝкь 18.194. (РКБEHO/RKBENO 2012).

дума ж. 1. 'дума, единица от човешката реч, съставена от един или няколко звука, която изразява определено понятие'. 2. 'дума, говор, устна реч, говорене'. 3. 'дума, това, което се казва; нещо издумано, изречено'. 4. 'изказано мнение, преценка, мисъл за нещо'; 'една дума едно нещо, нещо кратко'. (РКБЕНО/RKBENO 2012); И почѐха да ду̀мать по́редом вл(а)д(й)ците съкый свол ду̀ма...; ху̀лните нюговы ду̀мы; ... ако ѝма ду̀ма нѐка ду̀ма като́ тїа сѝчкы (Троян дам. 274) (Иванова/Ivanova 1967).

\section{РЕЧ - ХУРАТА - ЗБОР}

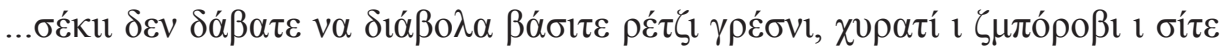

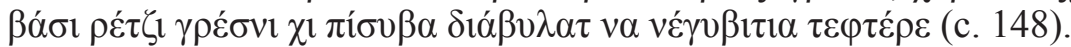

В случая, свързано с контекста, може да се приеме, че лексемите в синонимния ред са употребени със значение 'реч, изказани думи, приказки'.

Употребата на диалектната дума збор, характерна за македонските говори, показва какъв евентуален първоизточник са използвали среднородоп-

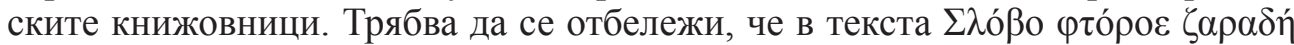

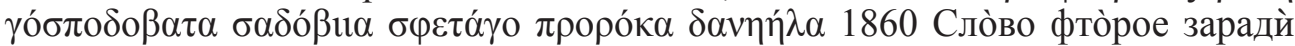
го̀сподовата садо̀вийа сфета̀го проро̀ка Данийла 1860 (с. 147-155) се откриват цели пасажи от текста, писани на диалект от югозападните краища на българското езиково землище.

збор м. 'дума' ЮЗБ (БЕР/ВЕR 2002).

реч - цслв. р'ъчь ж. 'реч, говор; обвинение, вина; работа' (Бончев 1995); рғч ж. 1. 'реч, изказани думи, приказки'. 2. 'повеление, заповед, нареждане'. 3. 'реч; обширно слово, посветено на неща'. има̀ и една̀кь много ду̀мы за ты̀зи р'ъчь. амй гы оста̀вихме. 38.284б (РКБЕНО 2012); и отъ ть̀зи р'ъч оста̀ като̀ свњєзань (Троян. дам. 63) (Иванова/Ivanova 1967). 


\section{СЛОВУ - ХУРАТА}

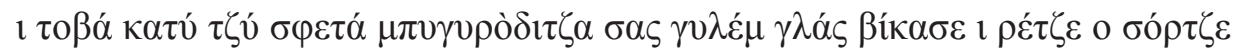

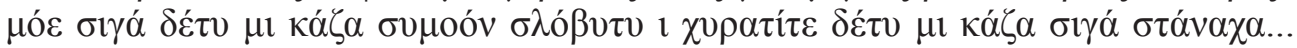
(c. 244).

Лексемата слово е употребена със значение 'разум, истина, откровение'.

слово с. 1. 'слово, вид религиозно произведение, поучително или похвално слово'. 2. 'разум, истина, откровение' (РКБЕНО/RКВЕNO 2012); цслв. слово с. 'слово, реч, дума; заповед; разум; разговор; отговор; мнение; полза' (Бончев/Bonchev 1995).

...слово на рождьство́ прњс(в)тые 29; И щъхме до ту̀ка да съврьшиме сло̀вото 159 (Троян. дам. 29; 159) (Иванова/Ivanova 1967).

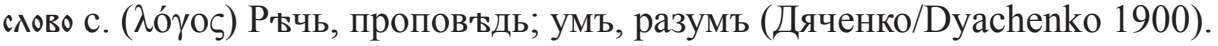

В единичен случай изписаната отпред гръцка заемка хората̀ е пояснена с битуваща в местните говори турска заемка лаф:

\section{ХОРАТА - ЛАФ}

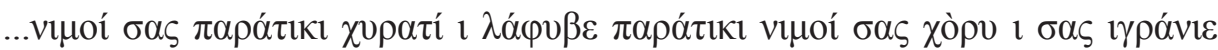

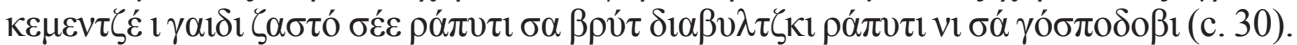

лаф - laf пер. 1. 'дума, слово, говор; приказка'. 2. 'бъбрене, празнодумство' (ТБР/TBR 1962).

В текстовете се открива и употреба на производни глаголи.

\section{ДУМАМ - ХУРАТУВАМ - ГЛАГОЛЕМ}

В два примера е налице задпоставена употреба на глагол думам, съответно като пояснение на гръцката заемка хоратувам и на форма на засвидетелствания в църковнославянски писмени източници облик глдголдти:

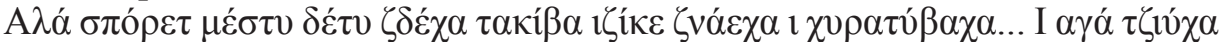

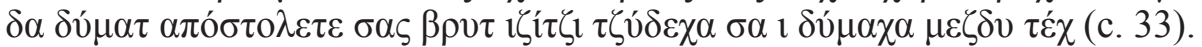

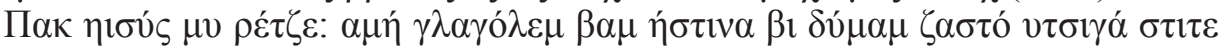
$\delta \alpha \beta i ́ \delta \imath \varepsilon \ldots .$. (с. 256).

хоратувам диал. 'говоря, приказвам' (PPOДД/RRODD 1974); грц.

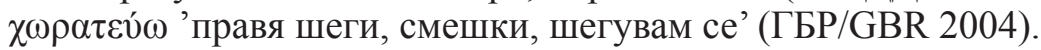

хоротя несв. 'говоря, приказвам нещо, хоратя'. и нѝкога ста̀рого не прятѝчеи съсъ ду́ма та му ду́ма насрѐща. тъкъмо и по́старь да му и хоротѝ (РКБЕНО/RKBENO 2012); хоротишь 2 л., ед.ч. 'говориш, разговаряш' 10, 301 (Троян. дам.) (Иванова/Ivanova 1967).

думам несв. 1. 'думам, служа си с устна реч; говоря'. амѝ не можа̀ да ду́ма... 2. 'думам; изричам нещо на глас, изразявам гласно мислите си; говоря, казвам'. 3. 'думам, обръщам се към някого с думи; говоря, казвам, приказвам някому нещо'. 4. 'думам, изтъквам нещо, изказвам определена мисъл, мнение, твърдение; заявявам нещо'. 5. 'разправям, предавам нещо, което зная, със свои думи (устно или писмено); разказвам'. 6. 'казвам, уведомявам за нещо'. (общо 13 значения) (РКБЕНО/RKBENO 2012); думам несв. 40, 128, $160 \ldots$ (Троян. дам.) (Иванова/Ivanova 1967). 
глаголем несв. стб. глдголдти (CP/SR 1999), цслв. глдголдти 'говоря, казвам' (Бончев 1995); глаголют ? несв. от стб. глдголдти 'говоря, казвам нещо'. (РКБЕНО/RKВENO 2012).

Успоредната употреба е засвидетелствана и в текстовете на Троянския дамаскин от XVIII в., което отново ни насочва към мнението, че е възможно да са включени в късните среднородопски дамаскини и текстове от по-стари български дамаскини, оформени с кирилско писмо:

...ть̀кьмо ако по ста̀рь ду̀ма и хоротѝ а ты слу̀шай и оучѝ се (Троян. дам., 10) (Иванова/ Ivanova 1967).

\section{СТЕПСАМ - СТОРЯ - СОЗДАМ}

Двата примера с употреба на синоними са от несъщинската част на Райковския дамаскин. Употребеният шрифт при писане на текстовете е небрежен скоропис, който в по-голямата си част трудно се разчита. Освен това се откриват няколко почерка, подобно на същинската част на сборника. И в двата случая на употреба първо е изписана глаголната форма от домашен, български произход, характерна за местния български говор: сторил. Съответно като втора съставка на синонимната двойка веднъж е предпочетена гръцката заемка степцал, а във втория пример - характерната за църковнославянския език глаголна форма сосдал:

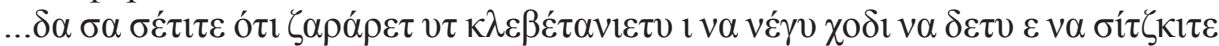

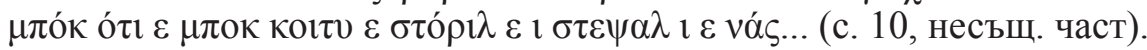

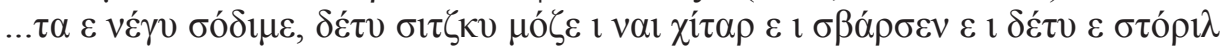

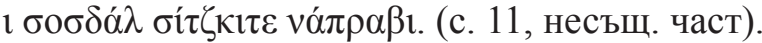

степцвам, степцувам несв. 'зачевам, създавам' (Смолянско, Ардинско, Асеновградско, Девинско, Маданско) (Стойчев/Stoychev 1965). - от аop. ocнова $(\varepsilon) \varphi \tau(\varepsilon) 1 \alpha \xi$ на нгр. глагол $\varphi \tau(\varepsilon) 1 \alpha v \omega$ 'правя, изготвям, създавам', със с- на мястото на ф- (БЕР/BER 2010).

сторя св. 1. 'сторя, създам с ръчен труд, направя, изработя'. 2. 'създам, сътворя (за Бога)' (РКБЕНО 2012); сторъ св. Така̀ да сто̀рж и а̀зь (Троян. дам., 113 (Иванова/Ivanova 1967).

создам - стб. съzи,длти 1. 'съзиждам, изграждам, построявам'. 2. прен. 'глася, подготвям, кроя' (CP/SR 2009); цслв. соZ,Алти 'съзиждам, създавам, изграждам' (Бончев/Bonchev 1995); създам св. 'създам; сътворя нещо, което досега не е съществувало; направя' (РКБЕНО/RKBENO 2012).

Важно е да се отбележи, че в текстовете на Тихонравовия дамаскин не се открива облик, характерен за църковнославянските писмени паметници.

\section{СИНУДУ - СБИРОВИЯ - ДЕРНЕК}

В синонимния ред сѝнуду - сбиро̀вия - дернѐк гръцката заемка сѝнуду е пояснена описателно:

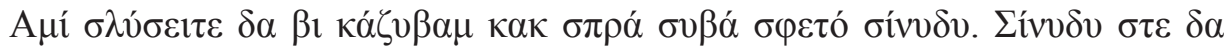

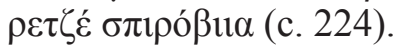

Вероятно преписвачите и преводачите на дамаскинските текстове не са открили подходяща дума от домашен, български произход, засвидетелствана в църковнославянските писмени паметници, поради което са включили съот- 
ветствие от домашен, български произход, битуващо в местните български родопски говори - сбиро̀вийа.

В останалите примери църковният термин от гръцки произход сиेнуду е пояснен с битуващата в местните български говори османотурска заемка дернѐк, която би била разбираема за читателите и слушателите на дамаскинските слова:

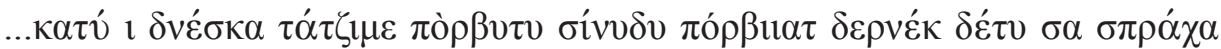

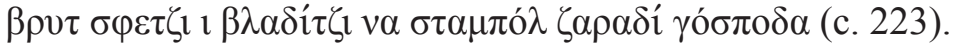

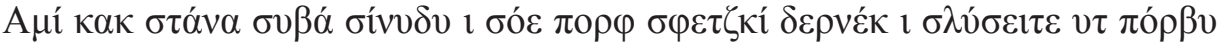

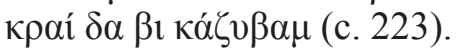
230).

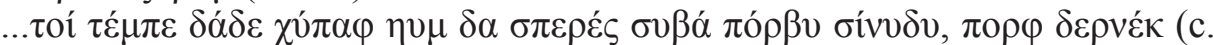

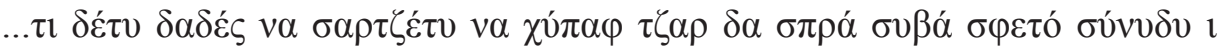

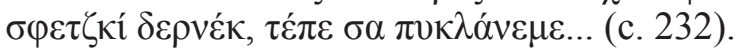

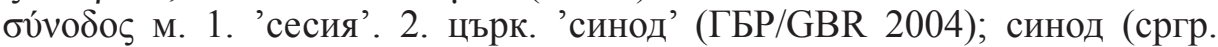

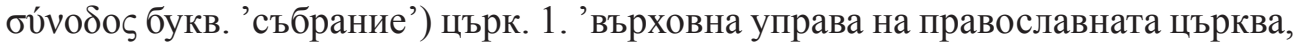
предимно от митрополити'. 2. 'сградата, в която се помещава такова управително тяло'. 3. 'църковно събрание'. (РЧДБЕ/RCDBE 1982).

дернек м. 1. 'дневна седянка'. 2. 'общоселско събрание'. 3. 'събиране на жени за приказки' (DTB 2002); dernek м. 1. 'забава, веселие, веселба'. 2. 'кръжок, събрание, съвет' (ТБР/TBR 1962).

сбиро̀вийа - збѝрица ж. 'разни дребни неща, подарък' (Смолянско, Асеновградско, Маданско); збироิ - вж. збйрица - Славеино, Виево, Кутела, Смолянско; Ардинско, Маданско) (Стойчев/Stoychev 1965); збйротина ж. 1. 'множество различни хора'. 2. 'много и най-различни неща на едно място' (Шумнатица, Солука, Кирково, Завоя, Домище, Жерка, Джерово, Дружинци, Чакаларово, Горно Капиново, Долно Капиново, Момчилградско) (Стойчев/ Stoychev 1983).

\section{ПАНИЦА - СТРАКИНА}

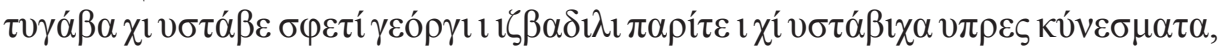

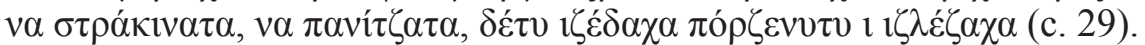

Под линия към нормализирания текст на Петковския дамаскин Хр. Попконстантинов отбелязва: „Оть гр[ъцката] дума стракиня (паница) общеупотрьбителна (...са станали кату стракинени соадувеа)“ (Попконстантинов/Popkonstantinov 1889, 156).

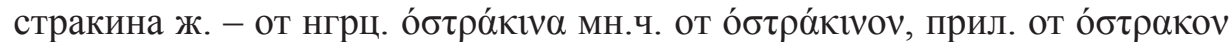
'черупка, парче, глинен съд', преосмислено в български като същ. ж.р. (БЕР/ BER 2010); стракина ж. диал. (от гр. обтра́к1оv) 'паница' (PPOДД/RRODD 1974).

паница ж. чслв. пхмицд 'колодезь, цистерна, чаша' (Дяченко/Dyachenko 1900); паница ж. 'разлат и дълбок глинен съд за ястие', 'глинен съд' (Старозагорско, Софийско, Плевенско, Ихтиманско, Кюстендилско и др.); срхр. па̀ница 'глинена чиния' (БЕР/BER 1996). 
В някои случаи думата от домашен, български произход е пояснена от две и повече думи от чужд произход, които битуват в местните български говори.

\section{ЯВНО - АЧИК - ЕШКЕРЕ}

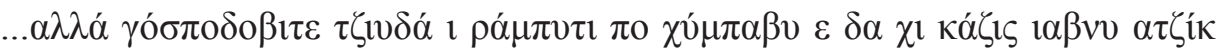
$\varepsilon \sigma \kappa \varepsilon ́ \rho \varepsilon$ (c. 131).

явну - стб. нав' нареч. 1. 'явно, открито, пред всички' (CP/SR 2009); цслв. ғав'ь 'явно, очевидно; познато' (Бончев/Bonchev 1995).

ачик тур. ас̧ıк прил. 'отворен, открит'. 2. 'просторен, широк'. 7. 'явен, нескрит, откровен' (ТБР/TBR 1969). 2002).

ешкере тур. aşikâre диал. eşkere нареч. 'явно, открито, очевидно' (DTB

\section{ТЕГЛИЛУ - ИЗЕТ}

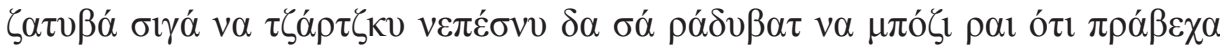

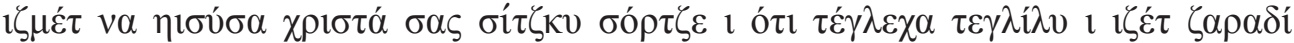
$\beta \varepsilon ́ p \alpha \tau \alpha \ldots$ (c. 53).

тегота ж. 'тегота; чувство за мъка, скръб; притеснение' (РКБЕНО/ RKBENO 2012).

теглило с. 'тегло, страдание, мъка' (Геров; Род. говори) (БEР/BER 2010); тегль несв. (Троян. дам.) (Иванова/Ivanova 1967)

изет ${ }^{2}$ м. 'труд, мъка' (DTB 2002); изет старо (от ар.-тур. eziyet) 'труд, мъка' (РPOДД/RRODD 1974); изет'о́вам гл. 'измъчвам са' (Смолянско, Ардинско, Асеновградско, Маданско) (Стойчев/Stoychev 1965).

Засвидетелствана е употреба на синонимни двойки, в които опозицията е съставена от чуждица и дума от домашен, български произход, битуващи в местния български говор.

\section{ЧУС (ЧУЖД) - АБАНДЖИЯ (ЯБАНДЖИЯ)}

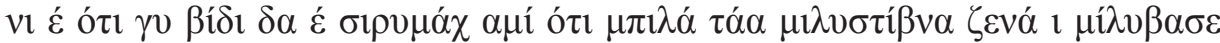

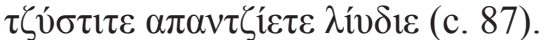

чус прил. 'чужд' - цслв. чужі́й и чуждій прил. 'чужд; необичаен' (Бончев/Bonchev 1995); чюжд прил. 1. 'чужд, който принадлежи на другиго, не свой'. 2. като същ., само ср.p. 'чуждо'. 3. 'чужд, с когото човек не е близък'; 'далечен, несроден' (РКБЕНО/RKBENO 2012).

yabanc1 м. 1. 'чужд, странен, външен'. 2. 'чужденец' (ТБР/TBR 1962); ябанджия м. (пер.-тур. yabanc1 ) 'чужденец, странник' (PPOДД/RRODD 1974).

\section{ПРЕСТИЛКА - МИНДИЛ}

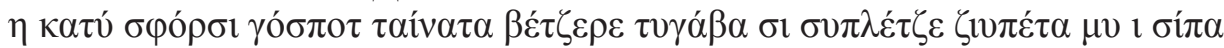

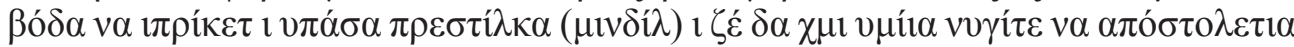
(c. 248).

престилка ж. (Северна, Югоизточна България) от престель 'престилка' (Родопите) от сегашната основа на пре-стеля (БEP/BER 1996). 
mendil м. 'кърпа за нос' (ТБР/TВR 1962); мендил м. 'престилка'; миндил м. 'домашна покривка за маса, месал' (DTB 2002); миндиль м. 1. 'домашно изработена престилка' (Смолянско, Асеновградско; Кръстополе, Ксантийско) (Стойчев/Stoychev 1965).

\section{КУЛАЙ - ЛЕКУ}

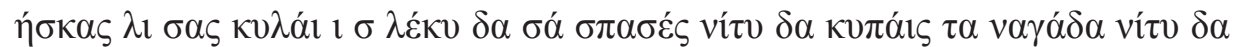

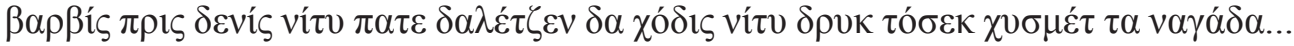
(несъщинска част, с. 2).

леко с. 'леснина'; леко прил. ...пак кога̀ пофа̀тишь нъщо и позна̀ешь студѐно ли е ил(и) то́пло, тѐжко ли е илѝ лѐко... (Троян. дам., 304) (Иванова/Ivanova 1967); цслв. лєгокz, лєгка, лєгко прил. 'лек, а, о' (Бончев/Bonchev 1995).

кулай м. тур. kolay 1. прил. 'лесен, немъчен'. 2. нареч. 'лесно, леко, без труд'. 3. с. 'леснина, средство, способ, цака' (TБР/TBR 1962).

Открива се и употреба на двойка синоними от домашен, български произход. В едни случаи едната лексема е характерна за църковнославянския език:

\section{СМЕРТ - УМИРАЛКА}

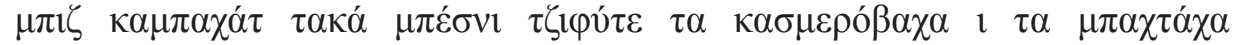

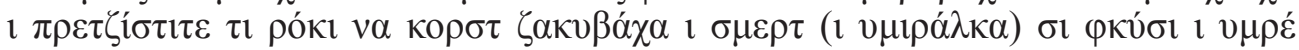
(c. 274).

Важно е да се отбележи, че поясняващата дума, характерна за местния говор, е поставена в крьгли скоби.

смерт м. цслв. смерть м. смерть $\theta \alpha v \alpha \tau о \varsigma$ смерть (Дяченко/Dyachenko 1900).

умира̀лка ж. 'смърт' (Смолянско, Ардинско, Асеновградско) (Стойчев/ Stoychev 1965); умирам несв. 'умирам, преставам да живея; издъхвам, заги-

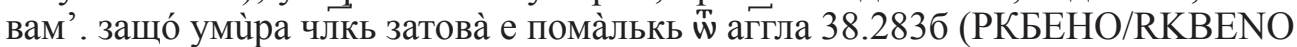
2012); оумира несв. (Троян. дам.) (Иванова/Ivanova 1967).

В други примери и двете лексеми са засвидетелствани в църковнославянски писмени източници, а битуват и в местните български говори:

ПОРС (ПРЬСТ) - ЗЕМЯ

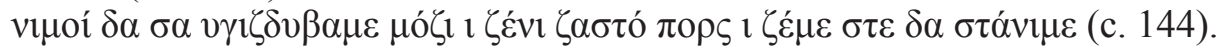

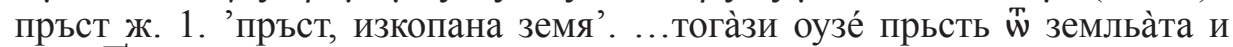
създа̀де члка 15.131б. (РКБЕНО/RKBENO 2012); цслв. персть сж. 'пръст, прах, пепел' (Бончев/Bonchev 1995).

земля ж. 6. 'земя; рохкаво вещество, съставящо земната кора, което може да се изкопава; пръст'. ... и земьа и прахь съмь и пльть има̀мь като съкыи члкъ ... 17.167б (РКБЕНО/RKВЕNO 2012).

\section{ГОСПОД - БОГ}

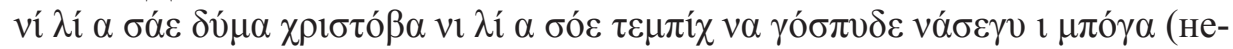
същинска част, с. 2).

За теонима бог в бележки под линия към нормализирания текст на Петковския дамаскин Хр. Попконстантинов отбелязва: „Тая дума е заета оть 
Неоф[итовото] Ев[ангелие]. Общоупотрябителната вь говора е Госпуть (И видеа бог...)“ (Попконстантинов/Popkonstantinov 1889, 143).

бог м. 1. 'Бог; в християнската религия висше, свръхестествено същество, създало и управляващо вселената; Господ, Творец, Създател' .

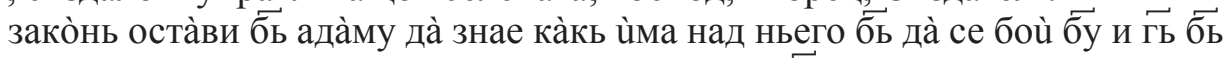
сичько му дарува ù сичько му простѝ 33.234б; амù гь това̀ поте́гли и распе́ се защо̀ е така е пùсано въ кнїгы пророчьскые такво̀зи да постра̀да $\overrightarrow{\mathrm{xc}} \widetilde{\text { бъ }}$ за а̀дама и за сѝчьки свъ`ть 35.262 (РКБЕНО 2012). В речниковата статия са отбелязани и устойчиви словосъчетания: до господа бога; жив господ бог; отида к господу богу; ради господа бога.

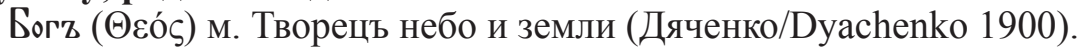

господ м. 'Господ; в християнството висше същество, считано за творец на битието; Бог'. и не бы дово̀льно гу бу милостѝвому да му со̀сувать тькь-

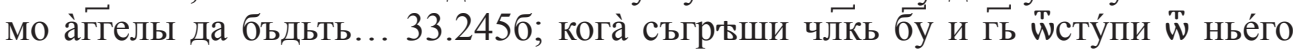
радѝ грьхь нье́говь... 5.27 (РКБЕНО/RKBENO 2012). В речниковата статия са включени устойчиви словосъчетания: до господа бога; жив господ бог; отида (прьида) к господу (богу); ради господа (бога).

Видно е, че и в Тихонравовия дамаскин се открива успоредна употреба на лексемите господ и бог.

господ м. Госпо, ь м. Господ, Божие име; господар; господин (Бончев/

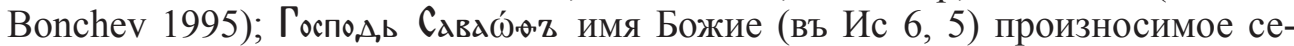
рафимами и означающее: Владыка сил небесных (Дяченко/Dyachenko 1900).

В църковнославянския речник има отделна речникова статия Бгъ и ГА, = то же что и Богъ; этот оборот рғчи употребляется иногда для выраженія превосходство предмета (Дяченко/Dyachenko 1900).

В трета група примери една от лексемите в синонимната двойка е характерна за местния говор, а другата е засвидетелствана в църковнославянски и в старобългарски писмени източници.

\section{ЧУВАМ - БРАНЕМ}

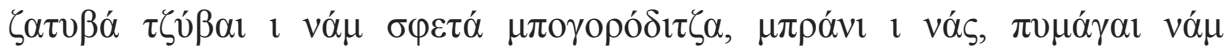
ко́

чювам несв. 1. 'пазя, вардя, браня, защитавам, чувам'. и ю́ставиха го та̀ чюва̀ лозїето за еи. годѝнь 5.33б; ù что чюваше аггль вра̀та еде́мьскы със ம́гнюно и пла̀мено орьжїе, сега шّ̈стьпѝ векье не чюва 35.265. 2. 'пазя, полагам грижи за нещо да не се загуби и повреди; чувам'. и ца̀рь 1 у́зе кнїга̀та ùз ру́ка ньегова и пода̀де ю что чюва кнїгы чьрко́вни 40.323. (РКБЕНО/RKBENO 2012).

сьгр'ьших и не знайах оेти ты стоѝшь прғв ме́не и бра̀ниш мù (Троян. дам., 322); о̀ти се сврьши ра̀бота ка̀кь иска̀ху и сега̀ ти нѝкой не бра̀ни (c. 362); б(о)гь не брани а̀гг(е)ла а̀ко ще злъ ако ли ще до̀бьрь защо̀ ако бы б(о) гь браниль... не бы быль дїаволь (с. 156) (Иванова/Ivanova 1967).

чýвам несв. 'пазя, браня' Чу́вай хи и бра̀ни каде́ту по̀дат! (Смолянско, Ардинско, Маданско, Асеновградско, Девинско) (Стойчев/Stoychev 1965). 
бранем несв. браня, стб. вранити 'възпирам, забранявам някому да извърши нещо' (CP/SR 1999); цслв. вранити 'возбранять, запрещать, не допускать' (Дяченко/Dyachenko 1900).

браня несв. 1. 'забранявам, преча на някого да извърши нещо'. 2. 'браня, защитавам нещо, пазя'. амù па̀кь ù това дрьво нема̀ше нико́и да го́ бра̀ни 38.2826. (РКБЕНО/RKВENO 2012);

амù съм и до дне́ска чѝста Фт чюжди мжжїе амù си чювам д('เ)вьство (Троян. дам., 69); те́бе ѝмаме ору́жїе щотоे ны чюва (с. 337); и що̀ чюваше аггель Еде́мскы със Огнғьно и пла̀менно Ору́жїе, Сега̀ ютстьпи векье не чюва (с. 372). (Иванова/Ivanova 1967).

врамити несв. 'браня, отблъсквам'; 'забранявам' (Бончев/Bonchev 1995).

Двата глагола в синонимна връзка чувам и браня са засвидетелствани в Тихонравовия дамаскин. Но докато браня се открива в църковнославянски речници, глагол чувам с такова значение не се среща. Успоредната им употреба в едно словосьчетание е характерна и за днешните говори в Среднородопието: Го̀спуть да ги чу̀ва и бра̀ни (Собств. набл.).

\section{БОХТАМ - БИЯ}

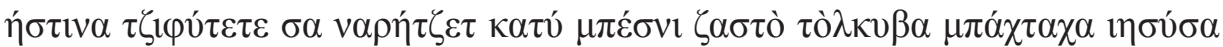

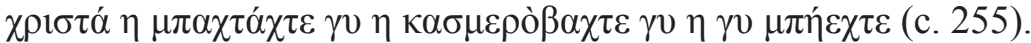

бия несв. 1. 'бия, нанасям на някого побой, удрям' 2. 'нападам, превземам с бой'. 3. 'бия, духам силно, шибам, бруля (за вятър)' (РКБЕНО/RКВЕNО 2012); цслв. вити несв. 'бия, удрям' (Бончев/Bonchev 1995).

бъхтя несв. 'бия, удрям, блъскам' (БЕР/BER 1971); боิххтам несв. 'бия, нанасям побой някому'; боิхтаница ж. 'бой, сбиване' (Виево, Кутела, Тикале, Смолянско) (Стойчев/Stoychev 1965.).

В текстовете се откриват също синонимни двойки, в които и двата члена са от чужд произход и битуват в местния български говор. Това може да се обясни с невъзможността на местните книжовници да открият подходяща дума от домашен, български произход, която да включат. Такъв е случаят с гръцкия църковен термин дида̀ксувам 'проповядвам', пояснен с битуващия в местните родопски говори турцизъм вазя със сходно значение. В по-ранните дамаскини като Тихонравовия и в Троянския дамаскин от XVII в. се употребява глагола проповядувам, за разлика от късните среднородопски дамаскини от втората половина на XIX в. Вероятно местните български книжовници, предимно свещеници, не са разполагали с подходяща литература на църковнославянски език, а и не са имали добри терминологични познания, свързани със свещенослужение на църковнославянски език.

\section{ДИДАКСУВАМ - ВАЗЯ}

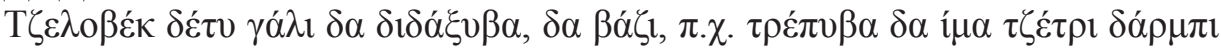

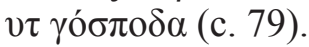

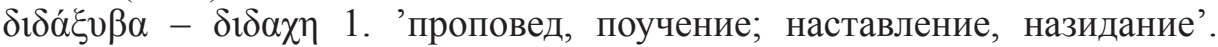
2. 'преподаване, учение, обучение' (ГБР/GBR 2004). 
проповядувам несв. 1. 'проповядвам; разпространявам идеи, възгледи, учение; прогласявам'. 2. 'предричам, предсказвам нещо; предвещавам' (РКБЕНО/RKBENO 2012); проповяду̀ва несв. ....и идѐ на пжт свой да пропов‘вду̀ва ѝме х(ристо)во (Троян. дам., 102) (Иванова/Ivanova 1967); цслв. проповъв,никъ м. (Дяченко/Dyachenko 1900).

vaiz м. мох. 'проповедник; проповед, поучение' (ТБР/TBR 1962); ва̀з'ам несв. 'произнасям слово, държа реч' (Смолянско) 2. 'съветвам' (Хвойна, Павелско, Асеновградско) (Стойчев/Stoychev 1965).

\section{ФУДУЛИН - КАБАДАИЯ}

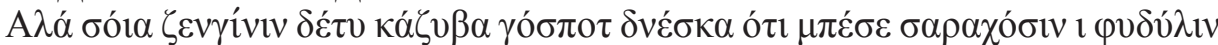

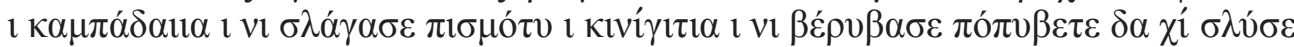

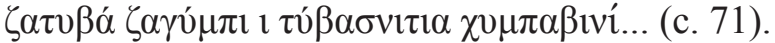

тур. fodul 'надменен, високомерен, надут, горделив' (TБР/TBR 1962); фудул(ин) м. (ap.-тyp. fodul) 'високомерен, надменен, горделив човек' (РРОДД/RRODD 1974).

каба̀даие м. 'човек, който се труфи и се гордее' (Смолянско, Ардинско, Асеновградско, Девинско, Маданско) (Стойчев/Stoychev 1965); kabaday1 1. 'нахалник, хвалипръцко, драка'. 2. 'смелчага, юначага' (ТБР/TBR 1962); кабадаия м. 'човек, който се облича наперено, конте'; кабадайлик, кабадайльк и кабадейлик м. 'надутост, напереност' (PPOДД/RRODD 1974).

Двата члена на синонимната двойка са турски заемки, разпространени в местните родопски говори.

\section{КУЧИЯ - АРАБА}

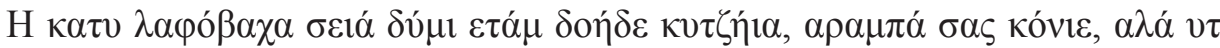

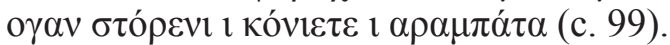

В примера с общоупотребимата в местните български говори турска заемка араба̀ се пояснява друга турска заемка с по-специфично значение кучѝя. араба ж. 'кола, талига' (DTB 2002); araba 1. 'кола, каруца, талига'. 3. 'кола' (ТБР/TВR 1962)

кочия ж. нар. остар. 'закрита конска кола; кола с покривало чергило'; 'файтон, каляска'; 'каруца' (БEP/BER 1979) - тур. kоçu остар. 'вид покрит файтон, карета' (ТБР/TBR 1962).

В единичен случай е налице изписване на селищно име (ойконим) в облици, характерни за официалния турски език и за местния български говор: Селеник - Солун.

\section{СЕЛЕНИК - СОЛУН}

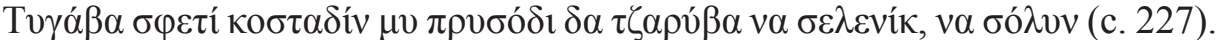

Солун СИ е българското име на централния град на Егейска Македония, гр. Солун в Гьрция. В статистиката на В. Кънчов за населението в Македония от началото на XX в. е отбелязано селищно име Солун, като в скоби са добавени названия Тесалоники и Селеник, т.е. гръцкото и турското название на селището (Кънчов/Kanchov 1970, 440). 


\section{2. Поясняване на думи в Златоградски сборник}

Както бе отбелязано по-горе, специфика на проучвания писмен паметник e, че е двуезичен. Срещу изписания оригинален гръцки текст, данни за който не са дадени, е представен български превод, оформен с гръцка графика. И въпреки че българският превод е на разговорен български език, в случая на местен родопски говор, са налице пояснени думи, чието съответствие е дадено в кръгли скоби. Интересно е да се види какви думи са пояснявани, а по този начин да се изясни, доколкото е възможно, каква е била целта на поясняването. Предвид спецификата на текстовете, включени в сборника (примерни текстове на писма; части от книги на Ветхия завет на Библията), може да се предположи каква е целта и какви са критериите на писачите при поясняването. Така например в пьрвата част - Писмовника - като критерий може да е установен вече своеобразен стандарт на оформление на текстовете, който се съблюдава от писачите. Това проличава и в поясненията към отделни писмовни текстове, с конкретни съвети как да бъдат оформени те. По-различни може да са критериите при оформлението на текстовете от Ветхия завет на Библията. Пояснените думи могат да се разгледат и откъм тематична насоченост, а и според последователността на изписване на новата дума и на съответствието ѝ, битуващо в местния родопски говор. Трябва да се отбележи, че и в този писмен паметник е включена терминологична лексика от чужд произход, както и църковнославянизми с добавени техни съответствия, с които са в синонимна връзка. Отлика от поясняването в Райковския дамаскин е, че обичайно всяка следходна дума, която е в синонимна връзка с включената предходна нова дума, е поставена в кръгли скоби. Освен това новоупотребената дума е изписана пьрва.

В първата част на сборника, която е писмовник, като цяло включените нови думи са от домашен, български произход и са характерни за църковнославянския език. С прибавените синоними от чужд произход, битуващи в местния родопски говор, съставителите на сборника, и по-точно преводачите на гръцките текстове, са целели да са понятни те за учениците. В местния говор, като част от родопските говори, широко разпространение са имали турцизми: тюджѐрин 'търговец' - tüccar араб. 'търговец' вм. търговец; илюм 'смърт' - ӧlüm тур. 'смърт' вм. смърт; каха̀р / кахо̀р 'скръб; загриженост' - kahır араб. 'грижа, безпокойство'; 'загриженост, скрьб' вм. загриженост, скръб; буба̀йку 'татко' - baba 1. 'баща, татко' (ТБР/TBR 1962) вм. татко; сеха̀тин 'свидетел' - шеха̀тин, шаха̀тин 'свидетел, очевидец', şahit (DTB 2002); şahit араб. 1. 'свидетел, очевидец' вм. свидетел; орнѐк 'мостра' - örnek 1. 'образец, модел' (ТБР/TBR 1962). Поясненията може би са били нужни и поради това, че включените думи от домашен, български произход не са били характерни за местните говори или по-точно облиците им са били характерни за църковнославянския език, който в известен смисъл също е бил неразбираем за българоезичните родопски християни. Например дума скорп (каха̀р) е засвидетелствана в църковнославянския език - цслв. скорьь 'скръб, тьга; болка' (Бончев/Bonchev 1995). Но в Тихонравовия дамаскин от XVII в. е в употреба облик скрьбь (РКБЕНО/RKBENO 2012). Облик смертса̀ е с членна 
морфема с формант $-c-$, характерна за родопските говори, в които има тройно членуване при имената - смерт смерть смърт (Дяченко/Dyachenko 1900). За златоградския говор са характерни облици кърфсь 'крьвта', ръисы 'ръжта', пърснь 'пръстта', при които наставки $-c b,-\mu b,-m ъ$ се добавят към основата на съществителните от ж.р., ед.ч., независимо дали окончава на гласен, или на съгласен звук. Докато в останалите родопските говори с тройно членуване при имената наставки -съ $(-c a,-c o),-$ нъ $(-н a,-н o),-$ ть $(-m a,-m o)$ при същ. имена от ж.р., ед.ч. се добавят към основи, завършващи на гласен звук.

Най-често включената нова дума е изписана първа, а след нея е даден нейният синоним, обичайно от чужд произход, който битува в местния български говор. В един единствен случай редът е променен, при изписването на синонимната двойка ла̀хана - зѐлие.

\section{ОТЕЦ - БУБАЙКУ / БОБАЙКУ}

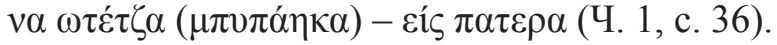

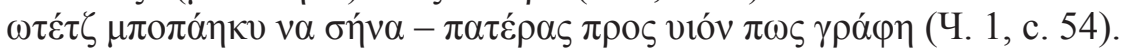

Сред многото изброени значения на думата отєцZ в речника на църковнославянския език на Дяченко не се открива значение 'баща, татко'. Най-близко значение е 4. Под именемъ отца иногда разумяется дядъ, прадядъ, прапрадядъ и проч. Останалите значения са: 1. Отец, Бог. 2. Христос - Отец будущаго вяка. 3. Богъ Отецъ - въ разсуждении тях, коихъ онъ создалъ во славу Свою и осиновилъ по благодати. 5. Отецъ называется иногда по достоинству по власти гражданской или духовной. 6. Отецъ есть составитель какого сочинения, учитель, наставник какой науки или знания. 7. Отецъ многих языковъ, т.е. Авраамъ... 8. Отец мнимы... 9. Отецъ иногда значитъ верховный начальникъ... (Дяченко/Dyachenko 1900). В речника на църковнославянския език на Ат. Бончев е отбелязан облик отєчъ, отча, отчє прил. 'отчев, бащин' (Бончев/ Bonchev 1995). Но в Тихонравовия дамаскин - български писмен паметник от XVII в. - думата се открива със значение 'баща, мъж по отношение на своите деца, отец' (РКБЕНО/RКВЕNО 2012). Видно е, че в българските възрожденски писмени източници думата се употребява със значение 'баща, родител'. Посоченото съответствие боба̀йку, буба̀йку, характерно за местните родопски говори, представлява побългарена форма от облик буба̀ на тур. baba 1. 'баща, татко' (TБР/TBR 1962) с прибавена наставка-айко. Обликът е разпространен главно в родопските говори на българския език в Смолянско, Асеновградско, Девинско, Маданско (Стойчев/Stoychev 1965).

\section{ТАРГОВЕЦ - ТУТЖЕРИН}

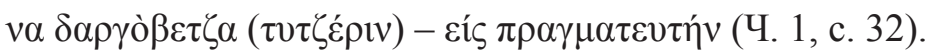

Дума д(т)арговец, не се открива в речниците на църковнославянския език. В тях е отбелязана лексема торжникъ 'търговец, меняч' (Бончев/Bonchev 1995); 'мяновщикъ денегъ, мяняло' (Дяченко/Dyachenko 1900), производно от торгъ, тzргъ 'площадъ торговая или судебная' (Дяченко/Dyachenko 1900). Но в старославянско-грьцко-латинския речник на Фр. Миклошич е засвидетел- 
стван облик тръговьць с данни за източник mon. serb. (Miclosich 1862-1865, 1006). В речника на книжовния български език на народна основа от XVII в. се среща лексемата тръговецъ 'търговец, лице, което се занимава с покупка и продажба на стоки' (РКБЕНО/RKВENO 2012). Това показва, че думата е била в писмена употреба по българските земи през XVII в. Но графичният ѝ облик с начална графема $\partial$ в Златоградския сборник сочи, че писачът няма точна представа как трябва да се изписва правилно, от което е видно, че тя е нова за неговия речник: тутжѐрин м. - т'уже̂̀р, т'уже̂̀рин (тур.) м. 'тьрговец', Родопите (Стойчев/Stoychev 1965) - чрез тур. tüccar 'тьрговци, тьрговец' от ap. tuggar мн.ч. tagir 'търговец' (БЕР/BER 2017).

\section{СМЕРТ - ЮЛЮМ}

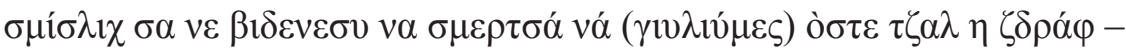

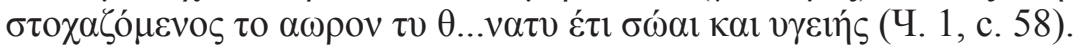

Облик смєрть се открива в църковнославянски писмени паметници: смерть $\theta$ áv $\alpha \tau$ ऽ 'смерть ' (Дяченко/Dyachenko 1900), докато в дамаскински текстове от XVII в., какъвто е Троянският дамаскин, се среща многократно и единствено обликът съмрьть (Иванова/Ivanova 1967, 371). В Тихонравовия дамаскин обликът е съмрьт (РКБЕНО/RKBENO 2012).

юлюм = ӧlüm м. 'смърт' (ТБР/TBR 1962); ил'у̀м (тур.) м. 'смърт' (Смолянско, Ардинско, Маданско, Асеновградско, Девинско) (Стойчев/Stoychev 1965).

\section{СФИДЕТЕЛИ - СЕХАТЕ}

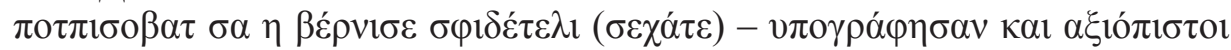
$\mu \alpha ́ \rho \tau v \rho \varepsilon \varsigma$ (Ч. 1, с. 60).

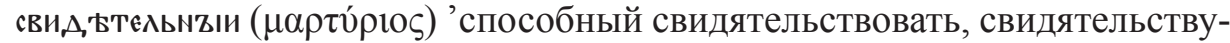
ющий' (Дяченко 1900).

ceха̀тин $=$ шехат(ин), шахат(ин) м. тур. şahit 'свидетел, очевидец' (DTB 2002).

\section{ОРНЕЦИ - МОСТРИ}

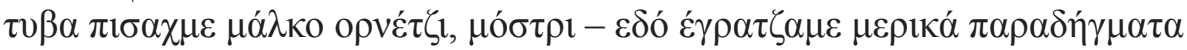
(Ч. 1, c. 68).

орнѐк м. юрнек тур. örnek м. 'образец, мостра, модел' (ТБР/TBR 1962).

мо̀стра ж. 'малко количество стока, което се показва или изпраща преди сделка; образец' (1859, Български книжици). От итал. mostra 'изложба; показ, парад; преглед; мостра, образец', което е производно от mostrare 'показвам ' (БEP/BER 1995).

Пояснени думи се откриват и във втората и третата част на сборника, включващи текстове от Ветхия завет на Библията.

\section{ВИНОПИИЦ - САРХОШ}

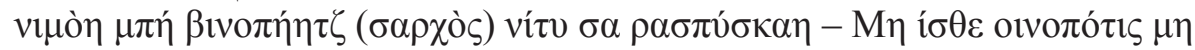

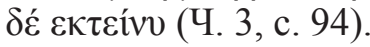


винопйиц м. стб. вимопиица м. 'винопиец, пияница' (CP/SR 1999); винопиец м. 'винопиец; лице, което обича да пие вино'. а̀ггель хранйтель пла̀че отъ винопййци а бъсоове се веселњтъ и ра̀дуватъ (РКБЕНО/RKBENO 2012); винопіець м. ... и бъсь има оу себъ си и винопіець: и заплюваха го... (Троян. дам. 228) (Иванова/Ivanova 1967).

capхòш м. sarhoş от перс. 'пиян, пияница; пияч' (ТБР/TBR 1962).

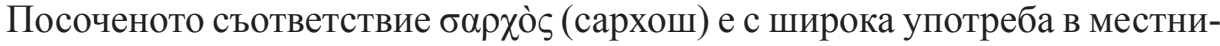
те български говори и като цяло в разговорния език.

ВОСНЕСИ - ФУДУЛЕ

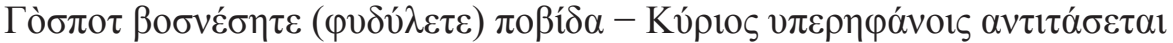
(Ч. 3, c. 36).

Плуралната членувана форма воснѐсите е с посочено османотурско съответствие фуду̀лете. В речника на църковнославянския език на Дяченко се открива прилагателно водносливъіи 'надменный, високомярный', както и съчетание возносити рогъ 'гордится' (не возносите рога) (Дяченко/Dyachenko 1900). Въпреки че в проучваните писмени източници не се открива облик воснѐсите, не става ясно дали думата е създадена от среднородопските възрожденски книжовници, или е заимствана от други възрожденски текстове. Изписаното съответствие, характерно за местните говори и за разговорния език като цяло, e fodul араб. 'надменен, високомерен, надут, горделив' (ТБР/ TBR 1962).

Засвидетелствана е и синонимна двойка производни глаголи воснйсам са - фоду̀ля са.

\section{ВОСНИСАМ СА - ФОДУЛЯ СА}

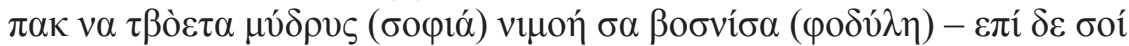

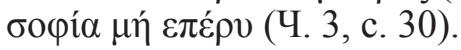

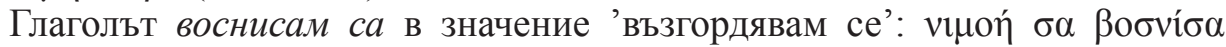

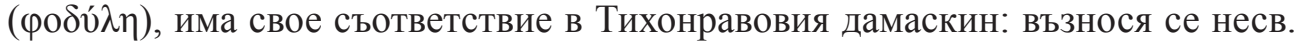
1. 'възнасям се, издигам се'. 2. 'възгордявам се, държа се надменно, големея ce' (РКБЕНО/RKBENO 2012). Но производно воснѐси (те) в значение 'тия, които са се възгордели, които се големеят и превъзнасят' не се открива.

Глагольт фодуेля $c a$ е възникнал на българска почва, като производен на съществителните fodul фодул 'надменен, горделив, високомерен' и fodulluk фодуллук 'надменност, горделивост, високомерие' (ТБР/TBR 1962).

\section{ИСРАИЛ - ЧИФУТЕТЕ}

царо̀ваше на Иерусалим (на исрайл (чифу̀тете) - липсва оригиналният грьцки текст (Ч. 3, с. 16).

В съчетанието царо̀ваше на Иерусалим (на исрайл (чифу̀тете) са включени ойконимът Иерусалим, етнонимът чифу̀тете и названието исрайл, което може да се възприеме като страната, където живеят чифутите (евреите). Названието е отбелязано в Тихонравовия дамаскин: Израил МИ Израил (РКБЕHO/RKBENO 2012). Включено е и в речника на Дяченко: 
Израихь м. так называются въ писании иудеи по праотцу своему Иакову, которому придано ето название Израиль (Дяченко/Dyachenko 1900). Турското съответствие с̧ıfit (обидно) 'евреин, чифутин' (ТБР/TBR 1962) е представено в български разговорен вариант чифут(ин), остаряло пренебрежително 'евреин' (РЧДБЕ/RCDBE 1982). Думата е разпространена и в териториалните говори.

Пояснени думи от домашен, български произход с думи от гръцки произход се откриват във втората и третата част на сборника, в които са включени текстове от Ветхия завет на Библията.

Най-широка употреба във втората и третата част на сборника има синонимната двойка СОФИА - МУДРУС / МУДРУС - СОФИА

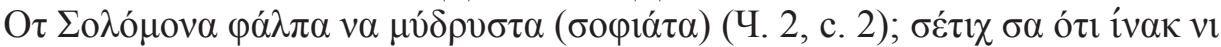

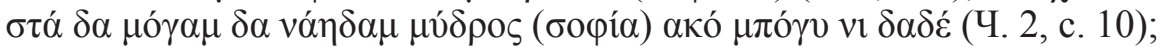

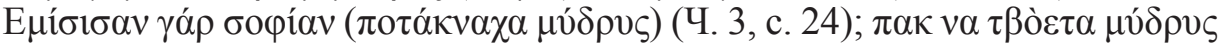

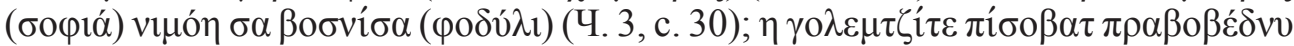

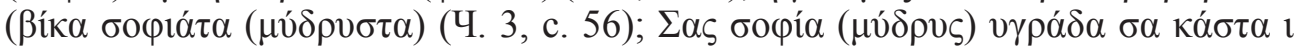

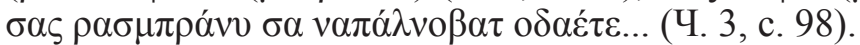

му̀дрос ж. цслв. м8,Арость ж. 'образ мыслей и чувствований' (Дяченко/ Dyachenko 1900); стб. мж,дрость ж. 1. 'мъдрост, разум'. 2. знание, познание. 3. мъдра мисъл, притча (CP/SR 1999); му̀дрость ж. 1. 'мъдрост, разум' . 2. 'знание, познание'. 3. 'мъдра мисъл, притча' (CP/SR 1999).

софйа грц. бофі́ $\alpha$ 'мъдрост' (ГБР/GBR 2004).

Както е посочено по-горе, облик мудрост е засвидетелстван в Тихонравовия сборник с две значения. Примерите от текстовете на Златоградския сборник също могат да се разделят според значението им:

1. 'мъдрост, възглед за света, знание':

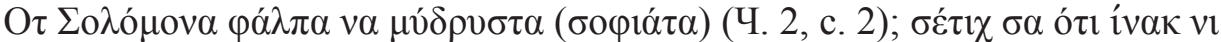

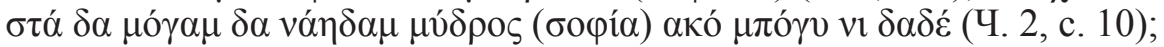

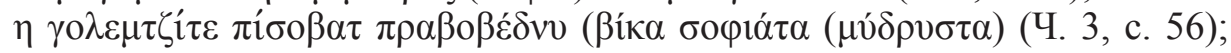

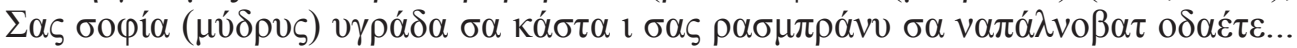
(Ч. 3 , c. 98).

2. 'мъдрост, благоразумие, разумност':

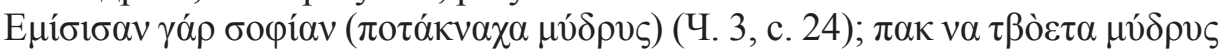

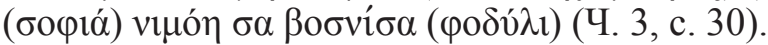

Интересно е, че докато във втората част на сборника първо е изписвана думата, характерна за църковнославянския език, в третата част, в която са включени пасажи от книга Притчи Соломонови на Ветхия завет на Библията, има непоследователност при поясняването на гръцката заемка. В едни примери при употреба на синонимната двойка тя е изписана отпред, а в скоби след нея е дадена грьцката заемка. В други случаи последователността е обратна. Видно е колебанието на преписвачите и на преводачите на текстовете дали да предпочетат гръцката заемка като основна, или църковнославянското ѝ съответствие. 


\section{ЗАКОН - НOMOC}

В Ч. 2 е включена лексемата от домашен произход закон, пояснена в ско-

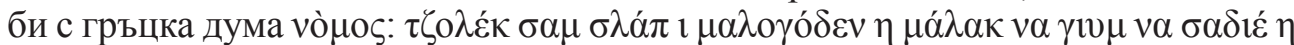

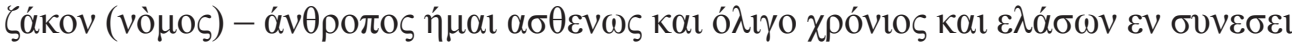
$\kappa \rho i ́ \sigma \varepsilon \omega \varsigma \kappa \alpha \imath$ vó $\mu \omega v$ (с. 12). Гръцкото съответствие е употребено в гръцкия текст и след това е добавено като пояснение в българския превод.

Лексемата vò $\mu$ ऽ е пояснена в гръцко-българските речници с българското съответствие закон (ГБР/GBR 2004).

закон м. zакоnz (vò $\mu$ os) 1. 'вообще узаконение, постановление'. 2. 'священное писание' (Дяченко/Dyachenko 1900).

Лексемата законь е с широка употреба в Тихонравовия дамаскин, като са отбелязани три нейни значения: 1. закон; система от нравствени и обредни правила, предписани от някое религиозно учение. 2. закон; установен ред, който трябва да се изпълнява безпрекословно в определен социален колектив; обичай, традиция, правило. 3. закон; разпореждане на държавна власт, което регулира определени сфери в обществения живот (РКБЕНО/RKBENO 2012). Открива се и в Троянския дамаскин: законь м. ...и разва̀лешь монастырскый за̀конь (с. 19); ...защо́ а̀ко ка̀жете то̀ щѐ да сѐ разва̀ли за̀конь от о́(ь)тци на̀ши прьда̀нїе (Троян. дам. 37) (Иванова/Ivanova 1967).

В Златоградски сборник лексемата е употребена със значение 'закон; система от нравствени и обредни правила, предписани от някое религиозно учение'.

\section{ЛАХАНА - ЗЕЛИЕ}

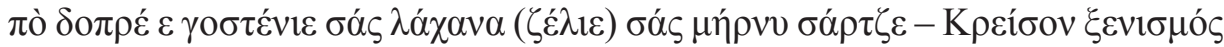
$\mu \varepsilon \tau \alpha \lambda \alpha \chi \alpha ́ v \omega \nu \ldots \varphi$...

Съответствието от домашен, български произход зѐлие се открива и в текстовете на Тихонравовия дамаскин със значение 'зеленчук; различни зелени растения, които се отглеждат в градини' (РКБЕНО/RKBENO 2012). Доста по-голям е семантичният обем на названието, отбелязан в речниците на църковнославянския език: ұєлїє 1. 'трава, зелень'. 2. 'овощь'. 3. 'лекарство'. 4. 'яд'. 5. 'порох' (Дяченко/Dyachenko 1900).

В гръцко-българските речници названието $\lambda \alpha ́ \chi \alpha \nu o(v)$ е пояснено с бъл-

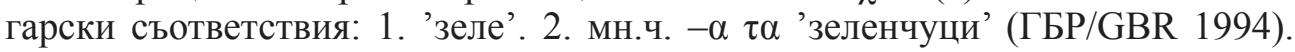
Според контекста в Златоградския сборник названието може да е употребено със значения 'зеленчук' и 'зеле'. В Родопски речник название ла̀хана, ла̀ана е отбелязано със значение 'зелка' и с разпространение в говори от Смолянско, Ардинско, Асеновградско, Маданско, Девинско (Стойчев/Stoychev 1965).

\section{4. Изводи}

От изнесените данни е видно, че поясняването на включени в текстовете нови непознати думи е характерно за среднородопските възрожденски писмени паметници от средата на XIX в. Пояснявана е терминологична лексика, свързана с различни сфери на религиозния и обществен живот на среднородопските българи християни: сѝнуду - збиро̀вия - дернѐк; го̀спод - бог; 
пея-псалмувам; дида̀ксува-ва̀зи; учйтел-да̀скал; запеча̀тен-мюхюрледйсан; пра̀зник - панагѝр (Райк. дам.); за̀кон - но̀мос, софѝа - му̀друс, сфидѐтели сеха̀те, орнѐци - мо̀стри (Зл. сб.). Но се среща и поясняване на нетерминологична лексика. Налице са отлики при поясняването в двата писмени паметника. В Райковския дамаскин синонимия се открива в повече тематични сфери:

○ предмети от бита: престѝлка - миндѝл; панйца - стра̀кина;

○ човешки дейности: чу̀вам - бра̀нем; бо̀хтам - бйя; ду̀мам - хурату̀вам - гла̀голем; стѐпсам - сто̀ря - сосда̀м;

○ човешки качества и др.: фуду̀лин - каба̀даия; лош - нюфелйт; чус абанжйя;

○ названия на селища: град / гра̀да - касабо̀; Селенйк - Со̀лун;

○ названия за единица време като хронология: час - саха̀т;

○ отвлечени понятия: кула̀й - лѐку; теглѝлу - изѐт; явно - ачйк ешкѐре.

В Златоградски сборник освен по-слабото тематично разнообразие, примерите със синонимия в отделни тематични сфери са единични:

○ роднинска терминология: отѐц - буба̀йку;

○ трудова дейност: тарго̀вец - тужѐрин;

○ човешки състояния и качества: винопйиц - сархо̀ш;

○ растителни видове: ла̀хана - зѐлие

Но пък, свързано със спецификата на текстовете във втората и третата част на Златоградски сборник, които са пасажи от Ветхия завет на Библията, многократно е включена синонимната двойка софѝа - му̀друс / му̀друс - софйа.

В текстовете на Райковския дамаскин се откриват цели синонимни редове (хората̀ - ду̀ма - лаф - збор - сло̀ву; ду̀мам - хурату̀вам - гла̀голем; стѐпсам - сто̀ря - сосда̀м; сѝнуду - збиро̀вия - дернѐк и др.), докато в Златоградския сборник синонимията е свързана изключително със синонимни двойки. Освен това в Райковския дамаскин синонимията се прехвърля и при производните думи: пра̀зник - панагѝр и празно̀вам - панигирѝсам; хората̀ - ду̀ма и ду̀мам - хурату̀вам, докато в текстовете на Златоградския сборник това е рядкост: воснѐси - фуду̀ле и воснйсам са - фоду̀ля са.

В два случая се открива поясняване на една и съща дума в двата писмени паметника. В първия пример църковнославянизмът смерт е пояснен в Райковския дамаскин с дума умира̀лка от домашен, български произход, характерна за местния говор, а в Златоградския сборник е пояснен с турската заемка юлюм. Във втория пример плуралната форма воснѐси е пояснена с турската заемка в местните говори фуду̀ле в Златоградския сборник, а в Райковския дамаскин обликът фуду̀лин е пояснен с друга турска заемка, каба̀даия:

смерт - умира̀лка (Райк. дам.); смерт - юлюм (Зл. сб.)

фуду̀лин - каба̀даия (Райк. дам.); воснѐси - фуду̀ле (Зл. сб.).

Важно е да се отбележи, че докато в текстовете на Златоградския сборник се пояснява основно нова дума, характерна за църковнославянския език, в текстовете на Райковския дамаскин се поясняват и думи от домашен, бъл- 
гарски произход, битуващи в местния говор (порс (пръст) - земя), както и чуждици, главно турцизми, също от местния говор: кучѝе - араба̀, фуду̀лин - каба̀даия.

Поясняването на думи в среднородопските възрожденски текстове не е изолирано явление в книжовната дейност през Възраждането. То е използвано от дамаскинари и други книжовници от различни краища на българското езиково землище. И се явява етап в работата по създаването на книжовен български език през XIX в.

\section{Литература}

АПБ 1987: Английски пътеписи за Балканите (края на XVI в. - 30-те години на $X I X$ в.). София: Наука и изкуство, 1987.

БЕР 1979: Български етимологичен речник. Т. 2, И - крепя. София: Академично издателство „Марин Дринов“, 1979.

БЕР 1995: Български етимологичен речник. Т. 4, минго - падам. София: Академично издателство „Марин Дринов“, 1995.

БЕР 1996: Български етимологичен речник. Т. 5, падеж - пускам. София: Академично издателство „Марин Дринов“, 1996.

БЕР 2002: Български етимологичен речник. Т. 6, пускам - словар. София: Академично издателство „Марин Дринов“, 2002.

БЕР 2010: Български етимологичен речник. Т. 7, слово - терясвам. София: Академично издателство „Марин Дринов“, 2010.

БЕР 2017: Български етимологичен речник. Т. 8, тесам - фякалка. София: Академично издателство „Марин Дринов“, 2017.

Бончев 1995: Бончев Ат. Църковнославянска граматика. Речник на иърковнославянски език. Велико Търново: ЕТ „Христо Червенаков - Митко“, 1995.

Бояджиев 1991: Бояджиев, Т. Българските говори в Западна (Беломорска) и Източна (Одринска) Тракия. София: УИ „Св. Климент Охридски“, 1991.

Ваклинова 1972: Ваклинова, М. Записки на Марин Караджов от Чепеларе. - Poдоnски сборник, 1972, 3, 207-224.

ВП 1992: Родолюбивий и благоразумний народе българский. Възрожденски предговоpu. Книга първа. 1806-1865. Събрал и наредил Д. Леков. София, 1972.

ГБР 1994: Гръико-български речник. София: Академично издателство „Марин Дринов“, 1994.

ГБР 2004: Гръцко-български речник. Второ преработено издание. Пловдив: „МАГ-77“, 2004.

Гиневски 2008: Гиневски, Хр. Миналото на Средните Родопи - ХІХ началото на ХХ век. Възраждане. Варна: УИ на ВСУ „Черноризец Храбър“, 2008.

Груев 1906: Груев, Й. Мочте спомени. Пловдив, 1906.

Дяченко 1900: Дьяченко, Г. Полный иерковнославянский словарь. Москва, 1900 (Репринт: Дьяченко Г. М. Полный церковно-славянский словарь. Москва: Издательский отдел Московского Патриархата, 1993.

Иванова 1967: Иванова, А. Троянски дамаскин. София: Академично издателство „Марин Дринов“", 1967.

Кънчов 1970: Кънчов, В. Македония. Етнография и статистика. - В: Васил Кънчов. Избрани произведения. Т. 2. София: Наука и изкуство, 1970. 
Маринов 1978а: Маринов, П. Поп Глигорко и неговото време. - Родопи, 1978, 7 , $22-24$.

Маринов 1978б: Маринов, П. Поп Глигорко и неговото време. - Родопи, 1978, 8, $36-38$.

Маслев 1988: Маслев, Ст. Неизвестен паметник на деловата писменост на народен български език от края на XVII век. - Palaebulgarica/Cmаробългаристика, 1988, 2.

Митринов 2000: Митринов, Г. Златоградски сборник. Писмен възрожденски паметник от средата на XIX век (1852 г.) и фототипно приложение. София: Македония прес, 2000.

Митринов 2005: Митринов, Г., Хр. Гиневски. Родопско книжовно наследство. Райковски дамаскин (ново пълно издание на текстовете в същинската част на сборника). Варна: Издателство на ВСУ „Черноризец Храбър“, 2005.

Мичева 2018: Мичева, В. Съюзната система в езика на новобългарските дамаскини. - В: Сб. Доклади от Юбилейната научна сесия „Съвременни тенденции в езиковедските изследвания “ (посветена на 85 години от рождението на проф. д.ф.н. Йордан Пенчев). София: Академично издателство „Марин Дринов“, 2018, 223-231.

Попконстантинов 1885: Попконстантинов, Хр. Петко войвода бранител на родопските българе до 1879 година. Черти от живота и подвизите му. Пловдив, 1885.

Попконстантинов 1888: Попконстантинов, Хр. Петко войвода бранител на родопските българе до 1879 година. Черти от живота и подвизите му. Пловдив, 1888.

Попконстантинов 1889: Попконстантинов, Хр. Материал за изучавание на родопското наречие. - Сборник за народни умотворения и книжнина, 1889, 1-2.

РКБЕНО 2012: Речник на книжовния български език на народна основа от XVII век (върху текст на Тихонравовия дамаскин). София: Издателство „Валентин Траянов“", 2012.

РРОДД 1974: Речник на редки, остарели и диалектни думи в литературата ни от $X I X$ и $X X$ век. София: Академично издателство „Марин Дринов“, 1974.

РЧДБЕ 1982: Речник на чуждите думи в българския език. София: Академично издателство „Марин Дринов“", 1982.

СР 1999: Старобългарски речник. Т. 1, А - Н. София: Издателство „Валентин Траянов“, 1999.

СР 2009: Старобългарски речник. Т. 2, О - У. София: Издателство „Валентин Траянов“", 2009.

Стефанов 2009: Стефанов, П. Неизвестни ръкописи в Шумен (XVI-XIX в.). - Tъpновски писмена. Алманах за Търновската книжсвна школа. 2009, 2, 240-252.

Стойчев 1965: Стойчев Т. Родопски речник. - Българска диалектология. Проучвания и материали. София: 1965, 2, 119-314.

Стойчев 1970: Стойчев, Т. Родопски речник. Първо допълнение. - Българска диалектология. Проучвания и материали. София:1970, 5, 152-221.

Стойчев 1983: Стойчев, Т. Родопски речник. Второ допълнение. Под редакцията на М. Сл. Младенов. - Родопски сборник, 1983, 5, 287-353.

Стоянов 1972: Стоянов, М. Райковски дамаскин. - Родопски сборник. 1972, 3, 225 307.

ТБР 1962: Турско-български речник. София: „Наука и изкуство“, 1962. 


\section{References}

APB 1987: Angliyski patepisi za Balkanite (kraya na XVI v. - 30-te godini na XIX v.) [English Travel Notes for the Balkans (end of the 16th century -30 s of the 19th century)]. Sofia: "Nauta i izkustvo", 1987.

BER 1979: Balgarski etimologichen rechnik [Bulgarian Etymological Dictionary]. T. 2. I - krepya. Sofia: Akademichno izdatelstvo "Marin Drinov", 1979.

BER 1995: Balgarski etimologichen rechnik [Bulgarian Etymological Dictionary]. T. 4. mingo - padam. Sofia: Akademichno izdatelstvo "Marin Drinov", 1995.

BER 1996: Balgarski etimologichen rechnik [Bulgarian Etymological Dictionary]. T. 5. padezh - puskam. Sofia: Akademichno izdatelstvo "Marin Drinov", 1996.

BER 2002: Balgarski etimologichen rechnik [Bulgarian Etymological Dictionary]. T. 6. puskam - slovar. Sofia: Akademichno izdatelstvo "Marin Drinov", 2002.

BER 2010: Balgarski etimologichen rechnik [Bulgarian Etymological Dictionary]. T. 7. slovo - teryasvam. Sofia: Akademichno izdatelstvo "Marin Drinov", 2010.

BER 2017: Balgarski etimologichen rechnik [Bulgarian Etymological Dictionary]. T. 8. tesam - fyakalka. Sofia: Akademichno izdatelstvo "Marin Drinov", 2017.

Bonchev 1995: Bonchev, At. Tsarkovnoslavyanska gramatika. Rechnik na tsarkovnoslavyanski ezik [Church Slavonic Grammar. Dictionary of Church Slavonic Language]. Veliko Tarnovo: ET "Hristo Chervenakov-Mitko", 1995.

Boyadzhiev 1991: Boyadzhiev, T. Balgarskite govori v Zapadna (Belomorska) i Iztochna (Odrinska) Trakiya [The Bulgarian Dialects in West (Aegean) and Eastern (Edirne) Thrace]. Sofia: Universitetsko izdatelstvo "Sv. Kliment Ohridski”, 1991.

Vaklinova 1972: Vaklinova, M. Zapiski na Marin Karadzhov ot Chepelare. [Notes of Marin Karadzhov from Chepelare]. - Rodopski sbornik, 1972, 3, 207-224.

VP 1992: Rodolyubivii $i$ blagorazumnii narode balgarskii. Vazrozhdenski predgovori [Patriotic and prudent Bulgarian people. Revival prefaces]. Kniga parva. 1806-1865. Sabral i naredil D. Lekov. Sofia, 1992.

GBR 1994: Gratsko-balgarski rechnik [Greek-Bulgarian Dictionary]. Sofia: Akademichno izdatelstvo "Marin Drinov", 1994.

GBR 2004: Gratsko-balgarski rechnik Vtoro preraboteno izdanie. [Greek-Bulgarian Dictionary. Second revised edition]. Plovdiv: "MAG-77”, 2004.

Ginevski 2008: Ginevski, Hr. Minaloto na Srednite Rodopi-XIX-nachaloto na XX vek. Vazrazhdane [The past of the Middle Rhodopes - 19 - the beginning of the 20th century. Revival]. Varna: Universitetsko izdatelstvo VSU "Chernorizets Hrabar", 2008.

Gruev 1906: Gruev, I. Moite spomeni [My Memories]. Plovdiv. 1906.

Dyachenko 1900: Dyachenko, G. Polnyj tserkovnoslavyanskij slovar' [A complete Church Slavonic Dictionary]. Moskva. 1900 (Reprint Dyachenko, G. M. Polnyj tserkovnoslavjanskij slovar'. Moskva: Izdatel'skij otdel Moskovskogo Patriarhata, 1993).

DTB 2002: A Dictionary of Turkisms in Bulgarian. Oslo: Novus forlag, 2002.

Ivanova 1970: Ivanova, A. Troyanski damaskin [Damascene from Troyan]. Sofia: Akademichno izdatelstvo "Marin Drinov", 1967.

Kanchov 1970: Kanchov, V. Makedonia. Etnografia i statistika [Macedonia. Ethnography and statistics]. - In: Vasil Kanchov. Izbrani proizvedeniya. T. 2. Sofia: "Nauka i izkustvo", 1970.

Marinov 1978a: Marinov, P. Pop Gligorko i negovoto vreme [Priest Gligorko and his time]. - Rodopi, 1978, 7, 22-24. 
Marinov 1978b: Marinov, P. Pop Gligorko i negovoto vreme [Priest Gligorko and his time]. - Rodopi, 1978, 8, 36-38.

Maslev 1988: Maslev St. Neizvesten pametnik na delovata pismenost na naroden balgarski ezik ot kraya na XVII vek [An unknown monument of business writing in vernacular Bulgarian of the end of the 17th century]. - Palaebulgarica/Starobalgaristika, 1988, 2.

Mitrinov 2000: Mitrinov, G. Zlatogradski sbornik. Pismen vazrozhdenski pametnik ot sredata na XIX vek (1852 g.) i fototipno prilozhenie [Zlatogradski sbornik. Written Revival monument from the middle of the 19th century (1852) and phototype edition]. Sofia: Makedonia pres, 2000.

Mitrinov 2005: Mitrinov, G., Hr. Ginevski. Rodopsko knizhovno nasledstvo. Raykovski damaskin [Rhodope Literary Heritage. Damascene from Raykovo]. Varna: Universko izdatelstvo VSU "Chernorizets Hrabar", 2005.

Micheva 2018: Micheva, V. Sayuznata sistema v ezika na novobalgarskite damaskini [Conjunction system in the language of the New Bulgarian damascenes]. - In: Sb. Dokladi ot Yubileynata nauchna sesiya "Savremenni tendentsii v ezikovedskite izsledvaniya" (posvetena na 85 godini ot rozhdenieto na prof. d.f.n. Yordan Penchev). Sofia: Akademichno izdatelstvo "Marin Drinov", 2018, 223-231.

Miklosich 1862-1865: Miklosich, Fr. Lexicon Palaeoslovenico-graeco-latinum. Emendatum actum. Vindobonae: Guilelmus Braumueller. 1862-1865.

Popkonstantinov 1885: Popkonstantinov, Hr. Petko voyvoda branitel na rodopskite balgari do 1879 godina. Cherti ot zhivota i podvizite mu [Petko Voyvoda Defender of the Rhodope Bulgarians until 1879. Features of his life and his exploits]. Plovdiv, 1885 .

Popkonstantinov 1888: Popkonstantinov, Hr. Petko voyvoda branitel na rodopskite balgari do 1879 godina. Cherti ot zhivota i podvizite mu [Petko voyvoda defender of the Rhodope Bulgarians until 1879. Features of his life and his exploits]. Plovdiv, 1888 .

Popkonstantinov 1889: Popkonstantinov, Hr., Material za izuchavanie na rodopskoto narechie [Material for studying Rhodopean dialect]. - Sbornikza narodni umotvoreniya i knizhnina, 1889, Vol. 1-2.

RKBENO 2012: Rechnik na knizhovniya balgarski ezik na narodna osnova ot XVII vek (varhu text na Tihonravoviya damaskin) [Glossary of the Literary Bulgarian Language on vernacular basis from the 17th Century (based on the text of the Tichonravov's Damascene)]. Sofia: Valentin Trayanov, 2012.

RRODD 1974: Rechnik na redki, ostareli $i$ dialektni dumi v literaturata ni ot XIX $i$ $X X$ vek [A Dictionary of Rare, Dialect and Outdated Words in our 19th and 20th Century Literature]. Sofia: Akademichno izdatelstvo "Marin Drinov", 1974.

RCDBE 1982: Rechnik na chuzhdite dumi v balgarskiya ezik [Dictionary of Foreign words in Bulgarian language]. Sofia: Akademichno izdatelstvo "Marin Drinov", 1982.

SR 1999: Starobalgarski rechnik [Old Bulgarian Dictionary]. T. 1, A - N. Sofia: Izdatelstvo "Valentin Trayanov", 1999.

SR 2009: Starobalgarski rechnik [Old Bulgarian Dictionary]. T. 2, O - U. Sofia: Izdatelstvo "Valentin Trayanov", 2009.

Stefanov 2009: Stefanov, P. Neizvestni rakopisi v Shumen (XVI-XIX v.) [Unknown manuscripts in Shumen (XVI-XIX c.)]. - Tarnovski pismena. Almanah za Tarnovskata knizhovna shkola, 2009, 2, 240-252.

Stoychev 1965: Stoychev, T. Rodopski rechnik [Rhodopean dictionary]. - Balgarska dialektologia. Prouchvania i materiali, 1965, 2, 119-314. 
Stoychev 1970: Stoychev, T. Rodopski rechnik [Rhodopean dictionary]. - Balgarska dialektologia. Prouchvania i materiali, 1970, 5, 152-221.

Stoychev 1983: Stoychev, T. Rodopski rechnik [Rhodopean Dictionary]. Vtoro dopalnenie. Pod redaktsiyata na M. Sl. Mladenov. - Rodopski sbornik, 1983, 5, 287-353.

Stoyanov 1972: Stoyanov, M. Raykovski damaskin [Damascene from Raykovo]. Rodopski sbornik, 1972, 3, 225-307.

TBR 1962: Tursko-balgarski rechnik [Turkish-Bulgarian Dictionary]. Sofia: "Nauka i izkustvo", 1962.

Доц. д-р Георги Митринов

Секция за история на българския език

Институт за български език към БАН

Бул. „Шипченски проход“ № 52, бл. 17

1113 София, България

mitrinov@abv.bg

Assoc. Prof. Georgi Mitrinov, PhD

Department of History of the Bulgarian Language Institute for Bulgarian language, BAS

52, Shipchenski prohod, B1. 17

1113 Sofia, Bulgaria

mitrinov@abv.bg 